\title{
2/B orman vasfını yitirmiş araziden tarım arazisine dönüşen taşınmazların toplu değerlemesi
}

\author{
Sultan Çinar*1 (D, Fatma Bünyan Ünel2 ${ }^{\mathbb{D}}$ \\ 1Mersin Üniversitesi, Uzaktan Algılama ve Coğrafi Bilgi Sistemleri Anabilim Dalı, Mersin, Türkiye \\ ${ }^{2}$ Mersin Üniversitesi, Mühendislik Fakültesi, Harita Mühendisliği Bölümü, Mersin, Türkiye
}

\author{
Anahtar Kelimeler \\ Toplu değerleme \\ Tarım arazisi değerleme \\ 2/B Arazisi \\ Yapay sinir ağları \\ Çoklu Lineer Regresyon \\ Analizi
}

\begin{abstract}
ÖZ
Taşınmaz değerleme; vergilendirme, sigortalama, kamulaştırma gibi birçok uygulamanın altlı̆̆ını oluşturmakta ve gün geçtikçe önemi artmaktadır. Toplu değerleme sistemleri kurularak modern yöntemlerle otomatik değer kestirimleri yapllabilmektedir. Değer kestirimlerinin hassas bir şekilde en az hata ile yapılabilmesi, gerçekleşen alım-satım değeriyle mümkündür. Tarım arazilerinin toplu değerlemesi için kriterler çeşitlilik göstermekte olup taşınmaz değerini arazinin büyüklüğü, yapısı, verimi ve konumu etkilemektedir. Bu çalışmanın amacı, Mersin ili Erdemli ilçesi Sarıkaya Mahallesi'ndeki 2/B arazilerinin resmi değerleri yardımıyla istatistiki yöntemlerden Çoklu Lineer Regresyon (ÇLR) analizi ve modern değerleme yöntemlerinden Yapay Sinir Ağları (YSA) uygulanarak değer kestirimi yapmaktır. Orman vasfını yitirmiş 2/B arazilerinin tarım arazisine dönüşerek satışının gerçekleşmesi için tespit edilen toplam 414 parsele ait resmi değerler ile model oluşturulmuştur. Performans analizinde $\mathrm{R}^{2}$, Ortalama Mutlak Hata (OMH), Ortalama Mutlak Yüzde Hata (OMYH) ve Karesel Ortalama Hata $(\mathrm{KOH})$ ele alınmıștır. ÇLR analizi için sırayla 0,$72 ; 0,25 ; 0,20 ; 0,07$ ve YSA için 0,88; 0,09; 0,07; 0,02 şeklinde bulunmuştur. Her iki modelin performansları incelendiğinde YSA modelinin resmi değere daha yakın olduğu tespit edilmiştir. Parsele ait konuma dayalı olarak resmi değerler, ÇLR ve YSA modellerinden elde edilen tahmin değerleri jeoistatistik analiz yapılarak değer haritaları üretilmiştir. Değer haritalarının görsel değerlendirmeleri sonucunda da resmi değerlere en yakın YSA tahmin değeri olmuştur.
\end{abstract}

\section{Mass valuation of real properties transformed from forest to agricultural land}

\section{Keywords}

Mass Valuation

Agriculture Land Valuation

2/B Land

Artificial Neural Networks

Multiple Linear Regression Analyze

\begin{abstract}
The real estate valuation is the basis of many implementation such as taxation, insurance, expropriation and its importance is increasing day by day. Automatic value estimates can be made with modern methods by creating mass real estate appraisal systems. It is possible for value estimates to be made inprecision and the leasterror by the aid of the actual purchas and sale value.The criteria for mass real estimate valuation of agricultural land various and the size of the land, its structure, yield and location affect the the real estate value. The purpose of this study is to make value estimation by applying multiple linear regression analysis (MLR) from statistical methods and artificial neural networks (ANN) from modern valuation methods with the help of official values of 2/B lands in Sarlkaya neighborhood of Erdemli zone of Mersin province. Land of $2 / \mathrm{B}$ that has lost its forest function has been estimated with the references official values of a total of 414 parcels identified for sale by turning in to agricultural land. In the performance analysis $\mathrm{R}^{2}$, mean absolute error (MAE), mean absolute percentage error (MAPE), and Mean Squared Error (MSE) were calculated. For MLR analysis, it was calculated as 0,$720 ; 0,25 ; 0,20 ; 0,07$ and 0,$88 ; 0,09 ; 0,07 ; 0,02$ for ANN. When the performances of both models were examined, it was found that the ANN model was closer to the real value. Based on the location of the parcel, the value maps was prepared by analyzing geostatistical to the real values, and the estimation values obtained from MLR and ANN models. As a result of visual evaluations of value maps, the ANN estimation value was the closest to real values.
\end{abstract}




\section{GíRIş}

Taşınmaz değerleme konusu gün geçtikçe ilgi odağı olmaktadır. Harita mühendisliği, inşaat mühendisliği, şehir ve bölge planlama, mimarlık, iktisat vb. disiplinler tarafından değerleme çalışmaları sürdürülmekte olup bazı kurumlar yeni bilirkişiler yetiştirme amaçlı eğitimler vermektedir (Hışır, 2009; Saraç, 2012). Sürdürebilirlik açısından mülkiyet insan hayatında büyük önem arz etmektedir. $\mathrm{Bu}$ kadar önem verilmesinin sebebi ise bir yatırım aracı olmasıdır. $\mathrm{Bu}$ yüzden taşınmaz değerlerinin belirlenmesi oldukça hassas bir konu olup, en doğru sonuca ulaşılması için çeşitli değerleme yöntemleri uygulanmaktadır (Mete \& Yomralıoğlu, 2019). Dünya genelinde, özellikle gelişmiş ülkelerin taşınmaz değerlemesi alanında ciddi deneyim birikimleri vardır. Bu ülkelerde günümüzün sorunları; süreçlerin uyumlaştırılması, standartlaştırılması, tanım birliktelikleri, meslek etiği ilkeleri olarak belirginleşmektedir (Köktürk, 2009).

Ülkemizde taşınmaz değerlemesi konusunun geçtiği birçok kanun, tüzük ve yönetmelik bulunmaktadır. Bunlara ek olarak her yıl yayınlanan bina birim maliyet cetveli, tapu harçları, gelir vergisinin asgari ölçütlerinin yayınlandığı tebliğler yer almaktadır. Türkiye Cumhuriyeti Anayasası'nın 46. Maddenin Sosyal ve Ekonomik Haklar ve Ödevler kapsamında kamulaștırma bedelinden bahsetmektedir (Anayasa, 1982). Türk Medeni Kanununun 899. Maddesinde taşınmazın ipotek edilebilmesi için taşınmazın değerinin tespitinden söz etmektedir (TMK, 2001). Vergi Usul Kanunu; 49, 72, 73 ve 74. Maddelerinde araziye ait asgari ölçüde birim değer tespiti için gerekli olan takdir komisyonu hakkında konuları ele almaktadır (Vergi Usul, 1961). Emlak Vergisi Kanununun 12-21. Maddesi arazi değeri, vergi oranları, tarh ve tahakkuku konuları yer almaktadır (Emlak Vergisi, 1970). Kamulaştırma Kanunu, 4, 7, 10, 11 ve 12. Maddesinde kamulaştırma ya da irtifak hakkı bedelinin mahkemece tespiti, tespit edilecek planı ve net gelir kriteri bulunmaktadır (Kamulaştırma, 1983). Kadastro Kanununun 36. Maddesinde arazi çalışmaları için emlak vergi beyanlarına göre Harçlar Kanunu tarifesi üzerinden kadastro harcı tahakkuk ettirilir (Kadastro, 1987). Tapu Kanununun 10 ve 14. Maddesinde denizlerin med ve cezrinden dolduğu yerler ile sahipsiz yerlerin satışında gayrimenkul değeri konusu geçmektedir. 18. Maddede kıymetlerin vergi matrahın baz alındığı belirtilmektedir (Tapu, 1983). İmar Kanunu arazilerin yapı inşası için arsa düzenleme ve yapı inşaa etme koşullarını içermektedir. Kanununun 18. Maddesi Arazi ve Arsa Düzenleme Esasları kapsamında bedel takdiri mevcuttur. 42. Maddesi Hâlihazır haritaların, imar planlarının ve Yapı Projelerinin Hazırlanması ve Uygulanması; Ek Madde 8'de imar planı değişikliğindeki değer artışı için rapor hazırlatılmaktadır (İmar, 1983).

Taşınmazdan vergi almak, kamulaştırmak ya da devletleştirmek, taşınmazlar üzerinde bir hak tesis etmek, anlaşmazlık durumunda taşınmaz kiralarını belirlemek, miras paylaştırmak vb. işlemleri yürütmek için taşınmazların piyasa değerlerinin bilinmesi gerekmektedir. Ayrıca özelleştirme, toprak düzenlemeleri, tescile esas işlemler, imar uygulamaları, kentsel dönüşüm gibi kamusal uygulamalar ile sermaye piyasası, bankacılık, kredilendirme, sigortacılık gibi özel sektör uygulamalarında taşınmazın değerine ihtiyaç duyulmaktadır (Açlar \& Çağdaş, 2008; Erdem, 2018a). Vergi, mahkeme, sigorta, vb. hesaplamaların piyasadaki alım-satım değerleri ile işlem yapılması, taşınmazların geçmiş değerleri ile günümüz değerlerinin karşılaştırılıp gelecekteki değer kestiriminin yapılması için taşınmaz değerleme sistemi kapsamında değerin, taşınmaz özelliklerinin tutulduğu bir veri tabanına ihtiyaç vardır (Erdem, 2017; 2019).

Almanya'nın Saxony-Anhalt eyaletinde tarım arazilerinin fiyatlandırılmasında kurumsal piyasanın rolünü araştırmak için bölgedeki tarım arazilerinin hektar başına düșen piyasa değerleri toplanmıştır. Tarım arazilerinin değerine etki eden kriterleri; toprak kalite numarası, parselin toplam boyutu, arazinin otlak alanı, bahçe alanı, orman alanı ve yapılabilecek tarımsal inşaat alanı şeklinde ele alınmıştır. Değer tahmini için üç model geliştirilmiştir ve bütün modellerde parselin boyutu ve toprak kalitesi değeri en fazla etkileyen kriter olarak bulunmuştur (Hüttel vd., 2016). Çin'deki tarım arazilerinin kiralarını etkileyen kriterlerin belirlenmesi konusunda araştırmalarını gerçekleştirmişlerdir. Kriterler araziden elde edilen tahıl miktarı, arazi boyutu, kiralama deneyimi, ailede çiftçilikle uğraşan kişi sayısı, doğal afetler, arazinin yüksekliği, platoların durumu, ekilebilir alan boyutu, arazinin dağlık olma durumu, arazinin düz olma durumu şeklinde sıralanmıștır. Çin hükümetinin tarım destekleyici yardımlarının \%10 artması üzerine tarım arazisi kiralarının da \%1 arttığı sonucuna ulaşmışlardır (Zhang vd., 2020).

Tarım arazilerinin değerini etkileyen kriterlerin tespit edilmesi için İzmir ilinin Bergama, Ödemiş, Torbalı, Bayındır ve Tire ilçesinde 21 kriter (parselin büyüklüğü, konumu, tasarruf şekli, eğim, şekil, vb.) (Öztürk vd., 2017) ile Konya ilinin Çumra ilçesinde 10 adet kriterle (nüfus, yerleşim birimine uzaklık, yola uzaklık, arazi genişliği, verimi, ulaşım olanakları, sulama olanakları, sağlık koşulları, arazi biçimi ve arazi piyasası) sulanabilir tarım arazilerin değerleri toplanarak gerçekleştirilmiştir. Analitik Hiyerarşi Prosesi (AHP), Gri İlişkisel Analizi (GIA) ile pazar değeri ve gelir yöntemi yöntemleri kullanılarak test edilmiştir (Karakayacı vd., 2016).

Tarım arazilerinin değerine etki eden kriterler araştırılırken aynı zamanda bu kriterlerin gruplandırılması işlemi yapılmıştır. Kriterler içsel (tarım arazisinin sahip olduğu hukuki haklar, fiziki özellikler ve tarımsal özellikler) ve dışsal etkiler (çevresel etmenler, bulunduğu konumdan kaynaklanan kriterler, üzerine uygulanmak istenen planlar) şeklinde kategorilere ayrılmıştır. Asiama vd., (2018) yapmış oldukları araştırmalarında Gana'daki kırsal bölgede yaşayan halkın görüşleri alınarak geleneksel kırsal alanların (tarım arazilerinin) değerlerinin belirlenmesi konusunu incelemişlerdir. Arazi değerine etki eden kriterler bölgede yaşayan halk tarafından belirlenip ağırlıklandırılmıştır. Arazinin değerine etki eden kriterler içsel etkiler; fiziksel özellikler, yasal özellikler ve tarımsal verimlilik şeklinde ele alınırken dışsal etkiler; konumsal özellikleri ve plan düzeni olarak grupların alt başlıkları incelenmiştir. Bölgedeki 
çiftçilerden yardım alınarak durum analizi, duyarlılık analizi (ağırlıklandırma) ve otomatik değerleme (GIS ortamında çoklu regresyon analizi) modeli yöntemleri ile kritelerin ağırlıklandırılması sonucunda fiziksel özelliklerin altında yer alan "yükseklik" kriterinin değer üzerine etkisinin en az olduğu sonucuna ulaşılmıştır. Yasal özelliklerden "arazi mülkiyeti" ve konumsal özelliklerinden "yola yakın olması" kriterlerinin değere en çok etki eden iki kriter olduğu sonucuna ulaşılmıştır. Taşınmaz değerleme konularına göre lisansüstü tezlerini inceleyen (Erdem, 2018b; Ünel \& Yalpır, 2019) iki çalışma bulunmakta olup arsa, arazi ve konut türleri kapsamında taşınmaz değerini etkileyen kriterler, kriterlerin gruplaması ve kullanılan yöntemlere göre irdelenmiştir (Ünel \& Yalpır, 2019).

Değer kestiriminde geleneksel, istatistiki, konumsal analiz ve modern değerleme yöntemleri kullanılmaktadır. Geleneksel değerleme yöntemleri toplu değerleme için yeterli olmaz iken istatistiki yöntemler ise genellikle modern yöntemleri doğrulamak amacıyla kullanılmaktadır (Ünel \& Yalpır, 2013). Örneğin Selim \& Demirbilek, (2009) yapmış oldukları çalışmada, konut kiralarının değer analizi hedonik regresyon modeli ile gerçekleştirilip yapay sinir ağ modeli ile de doğrulamaya gidilmiștir. Hedonik regresyon modeli ve YSA modelinin tahmin ettiği değerler ile fiili kira değerleri kıyaslanmış ve YSA modelinden elde edilen kira değerleri fiili kira değerlerine daha yakın bulunmuştur. Derinpınar \& Aydınoğlu, (2015) yapmış oldukları çalışmada nominal değerleme yöntemi ve modern değerleme yöntemlerinden bulanık mantık yöntemini kullanılmış ve taşınmaz türü olarak arazi ele alınmıştır. Nominal değerleme yönteminde her bir kriter için farklı ağırlıklandırma gerekiyorken, bulanık mantıkta faktörlere göre genel yaklaşımlar belirlendiği sonucuna ulaşılmıştır.

$\mathrm{Bu}$ çalışmada tarım arazilerinin değerine etki eden kriterlerin belirlenmesi ayrıca kriterlerin hangi yöntemle uygulandığı konularında literatür taraması gerçekleştirilmiştir. Geçmişten günümüze literatür incelendiğinde; değere etki eden kriterlerin her geçen yıl daha da fazlalaştığı gözlemlenmiştir. Bu durum da geçmişten günümüze değerin öneminin ve klymetinin arttığını gözler önüne sermektedir (Bahar, 2007; Savuran, 2008; Koç, 2011; Saraç, 2012; Karaca \& Yayar, 2014; Başer, 2015; Demetriou, 2016; Başer \& Kılıç, 2016; Öztürk vd., 2017; Özen \& Şişman, 2019; Zhang vd., 2020).

$\mathrm{Bu}$ çalışmanın amacı; orman niteliğini yitirip (2/B arazisi) orman sınırları dışarısına çıkarılan tarım arazilerinin resmi değer olarak kabul edilen Kıymet Takdir Komisyonu tarafından belirlenen değerleri "Çoklu lineer regresyon analizi" (ÇLR) ve "Yapay sinir ağları" (YSA) yöntemleri ile analiz etmek, modellerin performansları ve değer haritaları üzerinden karşılaştırma yapmaktır. Toplu değerleme işlemi için öncelikle kriterler literatürdeki çalışmalarda kullanılanlar dikkate alınarak tespit edilmiștir. Kriterlere göre 414 adet parselin verileri toplanmış ve değerleme için hazır hale getirilmiştir. Değer tahmini için ÇLR ve YSA yöntemleri uygulanarak modeller üretilmiş ve değer tahminleri sonuçları ile performansları analiz edilmiştir. Resmi değer, ÇLR ve YSA tahmin değer haritalarının oluşturtulmasında ArcGIS yazılımı kullanılmıştır. Taşınmaz değerleme konusu üzerine gerçekleştirilen bu çalışma, taşınmaz türü olarak 2/B tarım arazisinin seçilmesi, resmi arazi değerleri ile değerleme modellerinin üretilmesi ve tarım arazileri için modern değerleme yönteminin kullanılması yönlerinden özgünlük taşımaktadır.

\section{MATERYAL VE YÖNTEM}

\subsection{Materyal}

Doğu Akdeniz'de bulunan Mersin ili Erdemli ilçesine bağlı Sarıkaya Mahallesi, çalışmanın alanı olarak belirlenmiștir. Orman alanları ile çevrili olan mahallede yoğun 2/B arazilerinin bulunması nedeniyle özellikle seçilmiştir. Mahalledeki 414 adet 2/B arazisine ait; taşınmaz bilgileri (taşınmaz no, ada/parsel) ve kıymet takdir komisyonunun belirlediği 12 Şubat 2020 tarihli raporda belirtilen birim $\mathrm{m}^{2}$ bedeli (resmi değerleri) Erdemli Milli Emlak Şefliği'nden, parsellerin alanı ve konumsal özellik bilgileri (ilçeye, yola, en yakın köye vb. mesafeleri) Tapu ve Kadastro Genel Müdürlüğü'nün "parsel sorgu" uygulamasından temin edilmiştir.

\subsection{1. Çalışma Alanı Hakkında Bilgi}

Mersin ili, Erdemli İlçesinde yer alan Sarıkaya Mahallesi'nin rakımı $1300 \mathrm{~m}$ olup yaklaşık ilçe merkezine $31 \mathrm{~km}$, il merkezine $75 \mathrm{~km}$ uzaklıktadır (Şekil 1). Günün her saatinde toplu taşıma araçları olduğundan ulaşım problemi yaşanmamaktadır. Köyde ilköğretim okulu ve tam teşekküllü bir aile sağlık merkezi bulunmaktadır. Yazın hissedilen sıcaklık Erdemli'de ortalama $30-35{ }^{\circ} \mathrm{C}$ iken Sarıkaya Mahallesi'nde ortalama 20-25 ${ }^{\circ} \mathrm{C}$ 'dir. Bu nedenle yayla olarak da değerlendirilen mahallede nüfus 651'den (TÜİK, 2020) 5000'e kadar artış göstermektedir.

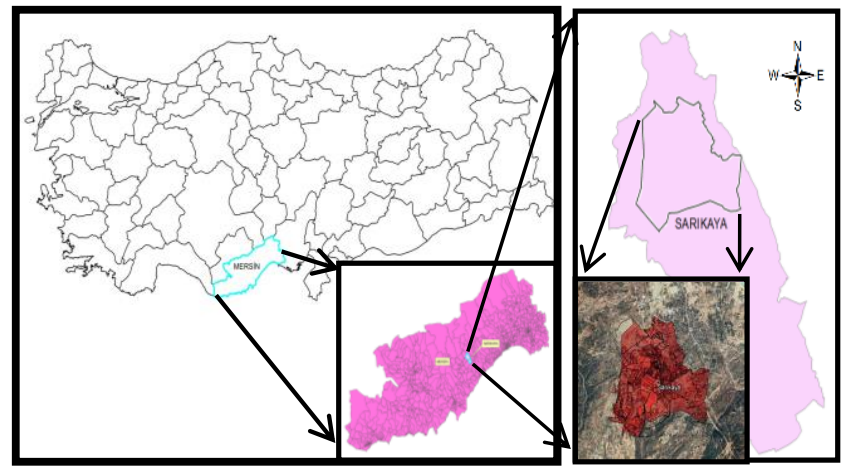

Şekil 1. Çalışma alanı

Mahalle sakinlerinin geçim kaynağı; bitkisel üretim ve hayvancılıktır. Hayvancılık olarak küçükbaş ve büyükbaş besiciliği gelişmiştir. Bitkisel üretim olarak bölgede en çok yetiştirilen tarım ürünleri; elma, şeftali ve kirazdır. Bunların yanı sıra ceviz, armut, ayva, buğday, arpa, nohut, domates ve salatalı da yetiştirilmektedir. Köyden on aileye Kaymakamlık tarafından Sosyal Riskleri Azaltma Projeleri kapsamında ikişer dönümlük arazilere dikilmek üzere iki bin kök 
bodur elma ağacı dağıtılmıştır. Bugün bu sayı beş bin civarına yükselmiştir. Köyde hem içme suyu hem de sulama suyu vardır. Su sondaj kuyularından temin edilmektedir. Mahallenin çevresi ardıç, meșe, sedir ağaçlarından oluşan ormanlarla kaplıdır. Sarıkaya Mahallesi'nin girişinde yer alan Kargagediği dünyanın en zengin en yaşlı sedir ormanına sahiptir (Sarıkaya Erdemli, 2020).

\subsubsection{Tarım Arazileri}

İnsanoğlu var olduğu sürece gıda asla son bulmayacak bir temel ihtiyaç olduğundan verimli tarım arazisine sahip olmak da ülkeler için stratejik bir öneme sahiptir. Yerel, bölgesel ve ulusal kalkınma çalışmalarının başarısı için tarım arazilerinin korunması, planlı bir tarımsal faaliyette bulunma, programlı pazarlama gibi konularda sürdürülebilir arazi yönetimini ele alıp coğrafi bilgi sistem entegrasyonu ile hayata geçirilmesi mümkün olabilmektedir.

Birçok ülkede (Brezilya, Almanya, Çin, Tayvan, İspanya) mutlak tarım arazisi olarak tespit edilen ve tapu kütüğüne niteliği bu biçimde belirtilen arazilerin tarım dışı amaçlarla kullanımına izin verilmemektedir. Benzer durum mera ve çayır ile orman arazileri gibi doğal kültür alanları için de geçerlidir. Ülkemizde de 2005 yılında yürürlüğe giren 5403 Sayılı Toprak Koruma ve Arazi Kullanımı Kanunu ile tarım arazileri korunmaktadır. Ülke, bölge, havza ve il düzeylerinde arazi varlığının kullanım alanlarına tahsisi ve rasyonel arazi kullanım planı hedeflerine ulaşılması, sadece piyasa koşullarına terk edilemeyecek kadar önemli bir konudur. Verimli tarım arazilerinin tarımsal üretim için korunması; arzın temini, hammadde sağlanması, sürdürülebilir bitkisel üretim için önemlidir (Sever, 2019).

Tarım arazileri genellikle orman ve mera alanlarının dönüşümü ile elde edilmektedir. Bayar, (2018) Türkiye'de tarım arazilerinin değişimini incelediği araştırmasında 2006-2012 yılları arasındaki TÜİK verilerini kullanarak arazi örtüsü bakımından tarım alanına dönüşen alanları sırasıyla şu şekilde belirtmiştir: En fazla tarım arazisine dönüşüm tarımsal alanların kendi aralarında dönüşümü, ardından ise orman yeri ve yarı doğal alanların dönüşümü şeklinde gerçekleştiğini belirtmiştir. Orman alanlarını ise 2,127 ha ile sulak alanlar takip etmektedir. Manisa, Köprübaşı 2008-2017 yılları arasında 4 sınıflama alanından meșe orman alanları azalır iken ekili tarım arazileri arttığ sonucuna ulașılmıștır (Yılmaz vd., 2018). Mersin, Akdeniz ilçesinde 2006-2014 yılları arsında 7 sınıflama yapılmıştır. Orman alanları, bitkinin az ya da hiç olmadığı alanlar azalır iken tarım arazileri, sera alanları ve yapay yüzeylerin arttığı gözlemlenmiştir (Göksel \& Balçlk, 2019).

Türkiye'de temel arazi varlıkları içerisinde en büyük değişim çayır-mera alanlarında yaşanmış ve bu değişim sürekli bu alanların aleyhine gelișim göstermiștir. Son 70 yıl içerisinde doğal çayır ve mera alanlarında \%61,5 oranında azalma olmuştur. Mera arazilerinin değişiminin belirli aralıklarda sınıflandırmak mümkündür. 1950-1960 yılları arasında Çiftçiyi Topraklandırma Kanunu kapsamında birçok mera çayır alanları köylülere tahsis edilmiştir. 1960-1970 yılları arasında mera olarak sınıflandırılan 7,5 milyon ha çalılık alan Orman Bakanlığı'nın kurulmasıyla birlikte Orman Bakanlığı'na devredilmiştir. 1980-1990 yılları arasında ise arazi sınıflandırma yöntemlerindeki değişimlerden ötürü mera alanlarında değişmeler meydana gelmiștir (Gökkuş, 2018).

Ormanlık alanlarının orman vasfını yitirmesi sonucu orman dışına çıkarılan araziler 2/B vasıflı araziler olarak cins değişikliğine gidilmektedir. 2/B arazisi tanımlanacak olursa (Şekil 2);

31.12.1981 tarihinden önce bilim ve fen bakımından orman niteliğini tam olarak kaybetmiş yerlerden:

-Tarla, bağ, bahçe, meyvelik, zeytinlik, fındıklık, fıstıklık, gibi çeşitli tarım alanları,

-Otlak, kişlak, yaylak gibi hayvancılıkta kullanılmasında yarar olduğu tespit edilen araziler

-Şehir, kasaba ve köy yapılarının toplu olarak bulunduğu yerleşim alanları

a)Devlet ormanı ise T.C. Maliye hazine adına

b)Tüzel kişiliğe haiz kamu kurumlarına ait orman ise bu kurumlar adına

c)Özel orman ise sahipleri adına orman sinırları dışına çıkarılır. Uygulama kesinleştikten sonra sahiplerinin müracaatı üzerine tapuda düzeltme ve tescil işlemleri yapılır (Orman, 1956).

"Orman kadastro komisyonlarınca Hazine adına orman sınırları dışına çıkarılan yerler, fiili kullanım durumları dikkate alınmak ve varsa üzerindeki muhdesatın kime veya kimlere ait olduğu ve kim veya kimler tarafından ne zamandan beri kullanıldığı kadastro tutanağının beyanlar hanesinde gösterilmek suretiyle, kadastrosu yapılarak Hazine adına tescil edilir" (Kadastro, 1987, Ek Madde 4). 2/B araziler tapu sicilinde tarım arazisi olarak tescil edilmektedir (Milli Emlak Genel Tebliği, 2020).

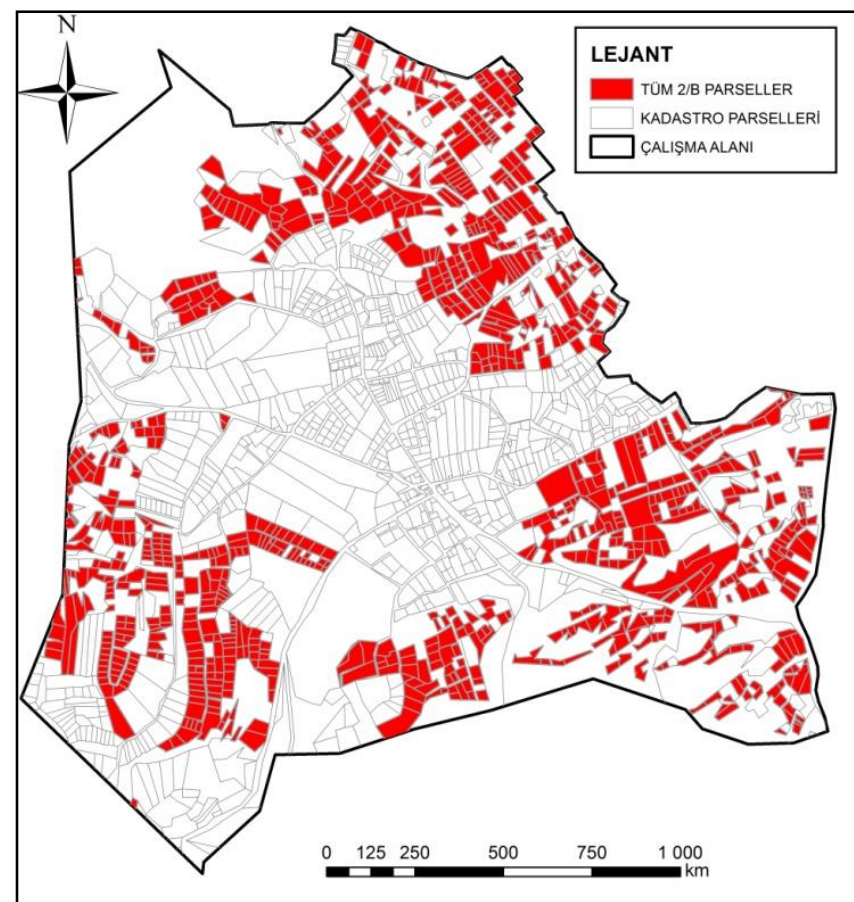

Şekil 2. Çalışma alanındaki 2/B arazilerin dağılımı

Orman vasfını yitirip 2/B arazisi olarak tescil edilen araziler bölge halkının satışına çıkmaktadır. Köy halkı, 
2/B arazilerini tarım arazisi olarak kullanabilmektedir. $\mathrm{Bu}$ durumda 2/B arazilerinin değer kavramı ortaya çıkmaktadır.

Genel anlamda taşınmazlar; türlerine, kullanım amaçlarına ve hizmet şekillerine göre farklılıklar göstermektedir. Bu farklılıklara göre arazi, arsa ve bina şeklinde sınıflandırılmaktadır. Binalar da hizmet şekillerine göre konut, ticari ve endüstri alanları olarak farklı türlere ayrılmaktadır. Arsa; şehrin gelişme öngörülerine göre yerel yönetimlerce bölünmüş toprak parçası iken, arazi; kentsel düzenlemeye girmemiş bağ, bahçe, tarla gibi çeşitli amaçlarla kullanılan ya da hiç bir şekilde kullanılmayan yeryüzü parçasıdır (Yalpır \& Ünel, 2016). Konut yapımına ayrılan arsa ile tarım faaliyetlerinin gerçekleştirildiği arazi iki temel grup olarak düşünülmüştür. Hazırlanan bu çalışmanın ana materyalini kırsal alanda bulunan tarım arazileri oluşturmaktadır. Bu tarım arazileri orman vasfını yitirmiş ve 2/B arazisi olarak tanımlanan tarım arazileridir.

2/B arazilerinin satışı gerçekleștiğinde tapu siciline "Tarım Arazisi" olarak tescil edilmektedir.
Taşınmazlarla ilgili olarak tapu sicilinde işlem yapmaya, illerde defterdar veya görevlendireceği memur, ilçelerde varsa milli emlak müdürü, yoksa mal müdürü yetkilidir (Hazine Taşınmazlarının İdaresi Hakkında Yönetmelik, 2007).

\subsubsection{Tarım Arazilerinin Değerine Etki Eden Kriterler}

Taşınmaz değerini etkileyen bir çok kriter bulunmaktadır. Arazi, arsa, konut, ticari, gibi taşınmaz türüne, bölgelere ve kișilere göre değișiklik göstermektedir. Tarım arazilerinin değerine etki eden kriterler literatür taramaları sonucunda elde edilmiştir (Şekil 3). (Keskin, 2003; Hurma, 2007; Başer \& Dizdar, 2009; Bulut, 2011; Koç, 2011; Karakayacı \& Karakayacı, 2012; Uematsu vd., 2013; Çoşar \& Engindeniz, 2011; Başer, 2015; Hüttel vd., 2016; Demetriou, 2016; Başer \& Kılıç, 2016; Karakayacı vd., 2016; Öztürk vd., 2017; Dedeoğlu \& Dengiz, 2018; Meyer \& Früh-Müller, 2020). $\mathrm{Bu}$ çalışmada bazı kriterlere ulaşılmadığından kullanılamamıştır.
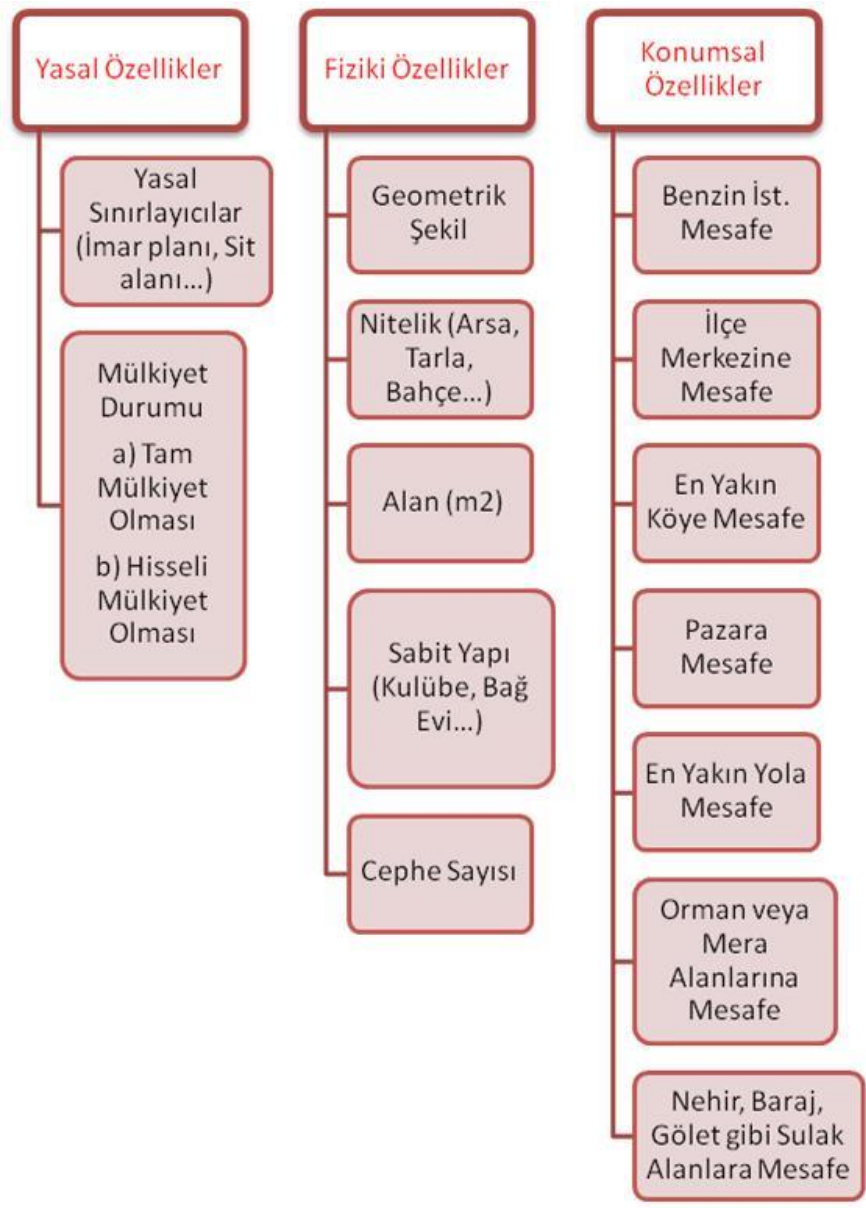

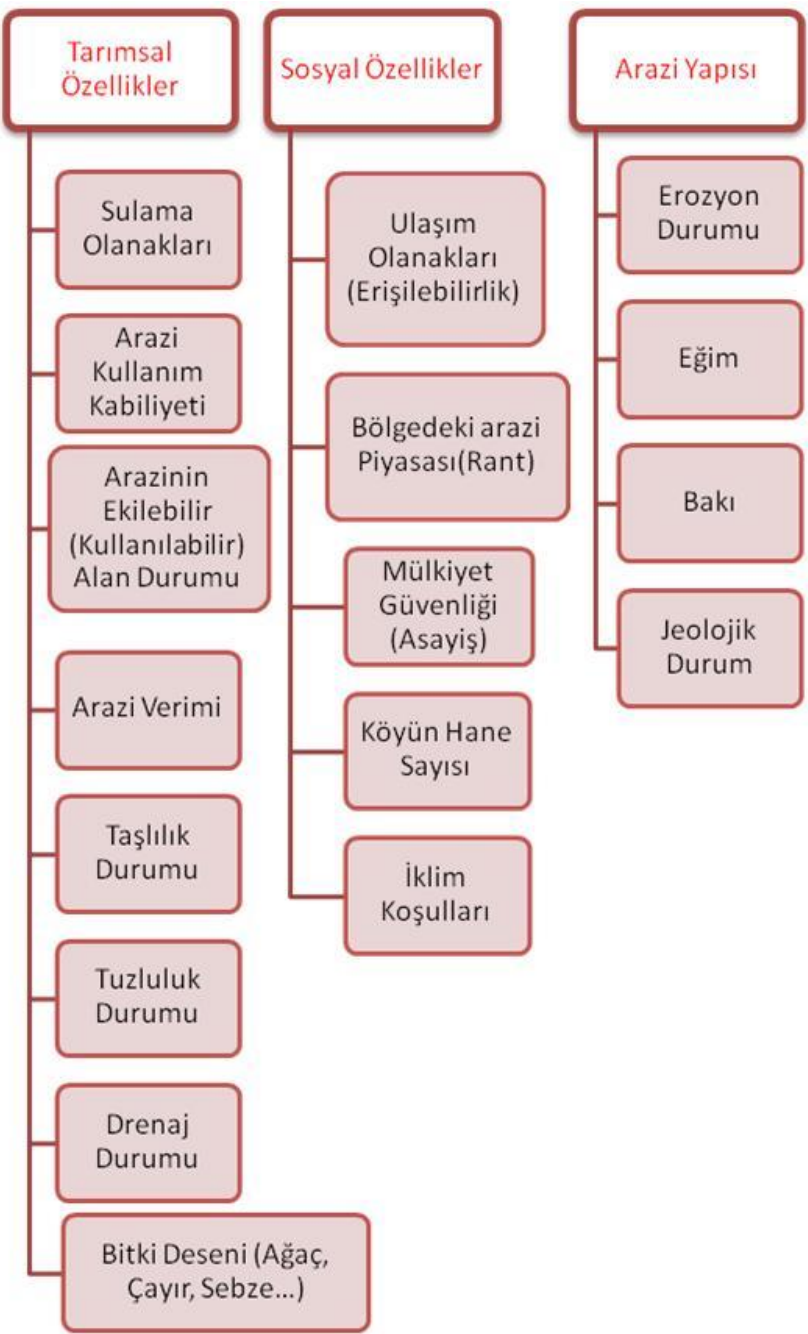

Șekil 3. Tarım arazilerinin değerine etki eden kriterlerin sınıflandırılması

\subsection{Yöntem}

Taşınmazın değer tahmin işlemleri yapılırken özellikle geleneksel yöntemlerde taşınmazın cinsi önemli bir özelliktir. Konutlar için maliyet yöntemi tercih edilirken arsalarda emsal karşılaştırma yöntemi kullanılarak değerleme yapılmaktadır. Tarım arazilerinin değerlemesinde ise genellikle gelir yöntemi tercih edilmekte olup kapitalizasyon oranı kullanılmaktadır (Engindeniz, 2010; Engindeniz vd., 
2015; Okan \& Engindeniz, 2016). Üzerinde ekili-dikili ürünlerden elde edilmiș ya da edilecek net gelir hesaplanıp kapitalizasyon oranına bölünmesiyle taşınmazın değeri hesaplanmaktadır. Bu çalıșmada ele alınan 2/B arazilerin cinsi de tarım arazisi kategorisindedir. Bahsi geçen literatür çalışmalarında bilgisayar yazılımları yardımıyla modern değerleme yöntemleri kullanılarak farklı taşınmaz türleri için matematiksel modeller oluşturulmaktadır. Regresyon, hedonik, nominal gibi istatistiki yöntemler ile yapay sinir ağları, bulanık mantık, genetik algoritma, kaba küme, rasgele orman gibi modern yöntemlere bașvurulmuștur. Tarım arazilerinin değerine etki eden kriterlerin ağırlıkları oranında değer tahmini yapılarak bir grup taşımmazın bir arada toplu değerlendirilmesinde, geleneksel yöntemlere kıyasla daha fazla olasılık ile objektif, hızlı ve doğru sonuçlar elde edilebilmektedir.

Kıymet Takdir Komisyonu tarafından belirlenen resmi değerler temel alınarak 2/B arazilerinin kriterler ölçüsünde değer tahmini yapılmıștır. Değerleme işlemi için istatistiki taşınmaz değerleme yöntemlerinden "Çoklu Lineer Regresyon Analizi" (ÇLR) ve modern taşınmaz değerleme yöntemlerinden "Yapay Sinir Ağları" (YSA) kullanılmıștır. ÇLR analizi için IBM SPSSv20 programı, YSA için ise MATLAB R2018a uygulaması kullanılmıștır.

\subsection{1. Çoklu Lineer Regresyon Analizi}

Çoklu lineer regresyon analizi iki ya da daha fazla değişken arasında bir bağlantı olup olmadığını, eğer bağlantı varsa bunun nasıl gösterileceğini anlatmak için kullanılır. Değişkenlerden birini veya değișkenin kategorisini önceden saptanan düzeylerde tutarak diğer değişkenin bu düzeye göre nasıl değiștiğini inceleme esasına dayanır. ÇLR modern istatistikte bilinenler yardımıyla bilinmeyeni bulma olarak da yorumlanır (Akış, 2013).

Birçok değişkenin yani kriterlerin aynı anda analiz edilip değerlemeye etkisi bulunabilmektedir. Bu yöntem sayesinde değer üzerinde hangi kriterin ne kadar etken olduğu belirlenebilmektedir. Örneğin tarım arazilerinin değerlemesinde arazinin alanı, mülkiyet durumu, geometrik şekli gibi kriterlerin değerini ne ölçüde etkilediği hesaplanabilmektedir.

Birden fazla bağımsız değişken kullanılarak yapılan ÇLR analizinde;

$x_{i 1}, x_{i 2}, \ldots x_{i k}$ bağımsız değișkenleri ve $y_{i}$ bağımlı değişkeni göstermek üzere en genel Eşitlik (1) kullanılmıştır (Gökgöz, 2020).

$y_{i}=\beta_{0}+\beta_{1} x_{i 1}+\beta_{2} x_{i 2}+\cdots+\beta_{k} x_{i k}+u_{i}$

$y_{i}$ : Bağımlı değissken (2/B tarım arazisinin resmi değeri),

$x_{i 1}, x_{i 2}, \ldots x_{i k}$ : Bağımsız değisskenler (alan, mülkiyet durumu, arazi kullanabilme kabiliyeti, ...)

$\beta_{0}$ : Sabit katsayl

$\beta_{1}, \beta_{2}, \ldots \beta_{k}$ : Değișken katsayıları șeklindedir.

$u_{i}$ : Bozulma veya hata terimi.

\subsubsection{Yapay Sinir Ağları}

Sinir sistemi, birbiriyle bağlantılı çalışan çok fazla sayıda sinirden meydana gelmiştir. Yapay sinir ağları; insan beyninden esinlenerek geliştirilmiş, ağırlıklı bağlantılar aracılığıyla birbirine bağlanan ve her biri kendi belleğine sahip işlem elemanlarından oluşan paralel ve dağıtılmış bilgi işleme yapıları; bir başka deyişle, biyolojik sinir ağlarını taklit eden bilgisayar programlarıdır (Şengöz, 2017). Yapay zekâ tekniği olarak da adlandırılan bu yöntem, insan beyninin öğrenme sürecinin tekrarlanmasıyla geliştirilmiştir (Alpaslan, 2015).

Yapay bir sinir ağının temel çalışma adımlarını şu şekilde sıralamak mümkündür (Beşer, 2015).

- Çalışma setinden uygun setin seçimi ve girdi vektörünün sinir ağına uygulanması

- Sinir ağının çıktı değerinin hesaplanması

- Sinir ağının çıktı değeri ile ulaşılmak istenen değer arasındaki hatanın hesaplanması

- Hataları en aza indirgeyecek sinir ağı ağırlığının hesaplanması

- Hatalar kabul edilir düzeye gelene kadar devam etmek

\section{Yapay Sinir Ağlarının Temel Bileșenleri}

Yapay sinir ağları, öğrenme algoritması ve aktivasyon fonksiyonu olmak üzere iki temel bileșenden oluşur.

Öğrenme algoritması, temel hedef eldeki verilerden yola çıkarak farklı olasılıkları hesaplamak ve gerçekleşebilecek ihtimalleri ortaya koymaktır. Yapay sinir ağlarının kullanım alanları artmaktadır (Gültepe, 2019). Yapay sinir ağlarında kullanılan çok sayıda öğrenme algoritmaları bulunmaktadır. En çok kullanılan öğrenme algoritmaları; Hebb, Delta, Geri Yayllma (Genelleștirilmiş Delta), Kohonen, Hopfield ve Enerji Fonksiyondur (Alpaslan, 2015).

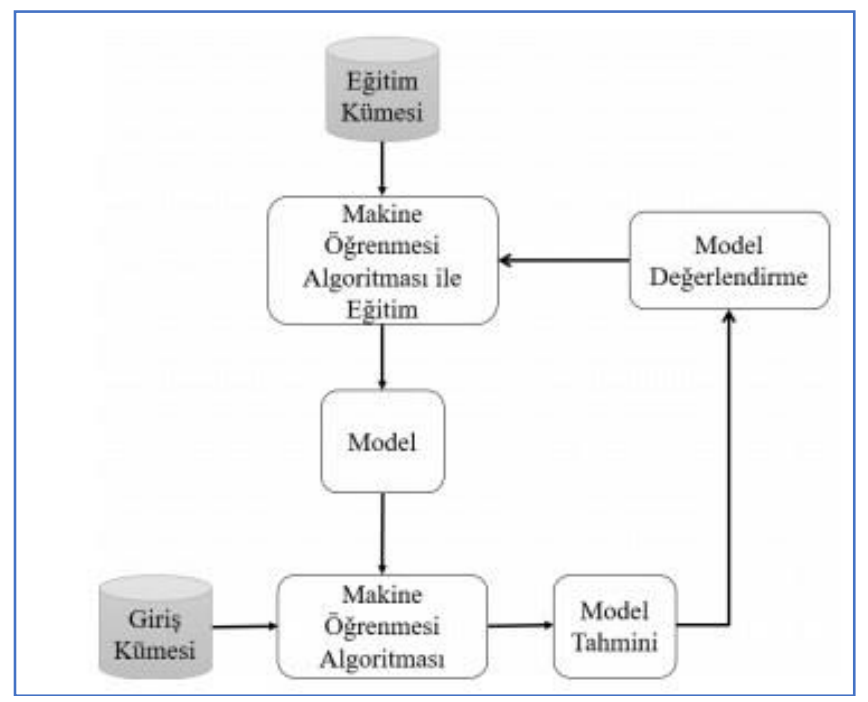

Şekil 4. Temel makine öğrenmesi (Gültepe, 2019)

Aktivasyon fonksiyonunda yapay sinir hücresi girdi verileri üzerinde işlem yaparak buna karşıllk gelen net çıtı sonuçları elde eder. Bu fonksiyon genellikle doğrusal değildir. Fonksiyonun doğru seçilmesi, performansı etkileyeceği için önem arz etmektedir 
(Öztürk \& Şahin, 2018). Geri beslemeli ağlarda, türevi kolay bulunabilen fonksiyon tercih edilmelidir. Günümüzde en yaygın olarak sigmoid fonksiyonu kullanılmaktadır (Şengöz, 2017).

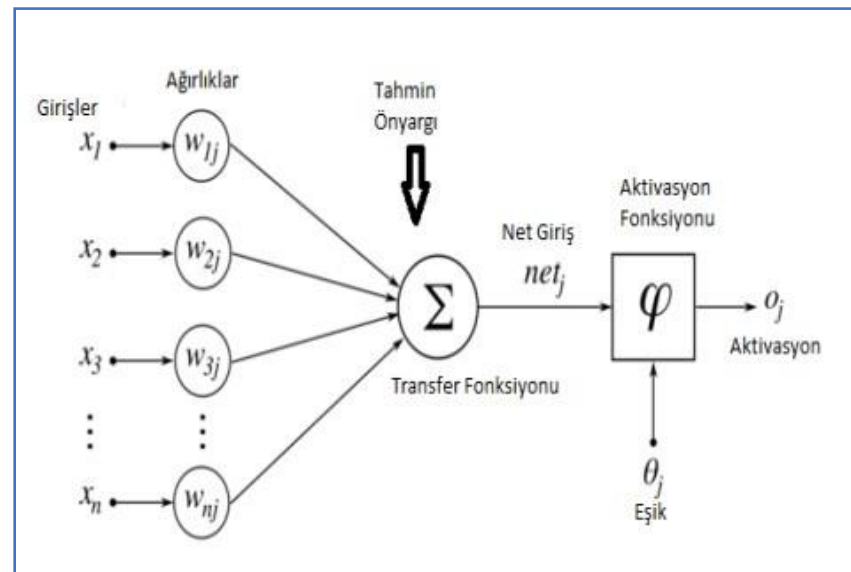

Şekil 5. Yapay sinir ağı (Öztürk \& Şahin, 2018)

- Sigmoid (lojistik) aktivasyon fonksiyonu; değeri 0 ve 1 arasına sıkıştırmasından dolayı bir olayın olma olasılığını bulan modellerde kullanılır.

- Tanh (hiberbolik tanjant) aktivasyon fonksiyonu; sigmoid fonksiyonuna benzer, fakat tanh -1 ile 1 arasında değer alır. Negatif sayılardan negatif, sıfırdan sıfır ve pozitiften pozitif değer döndürmesi avantajlarından biridir.
- ReLU (rectified linear unit) doğrultulmuş doğrusal birim; konvolüsyonel sinir ağlarında ve derin öğrenmede çoğunlukla kullanılır (Taşkıran, 2021).

Sistemin doğru olarak eğitilebilmesi için mutlaka sonuçları önceden bilinen bir eğitim setine ihtiyaç vardır. Sistem öncelikle bu eğitim setiyle eğitilir ve sonrasında sonucuna ihtiyaç duyulan problem veri setine uygulanır (Özkan \& Yalpır, 2005; Ergin, 2013). Yapay sinir ağları modellerinin uygulanmasında da bazı sorunlar meydana çıkmaktadır. Bu sorunlar:

- Yapay sinir ağlarının kullanımının kolay olmaması

- Farklı yapay sinir ağları arasında sonuçların tutarsızlı̆ 1

- Aynı yapay sinir ağı yazılımın sonuçlarında da farklılıklar olabilmesi

- Yöntemin oldukça uzun zaman süreci gerektirmesidir (Alpaslan, 2015).

Yapay sinir ağları modelinin kullanımında veri setinin homojen șekilde dağılımın sağlanması amacıyla veri sayısı istenen oranda dağılımı gerçekleștirilebilir. Genel anlamda \%70 eğitim ve \%30 test olarak oranlar belirlenmektedir. Böylelikle sinir ağının öğreneceği ve test edeceği verilerin kullanıcı tarafından belirlenmesi sağlanmaktadır. Hazırlanan bu çalıșmada da aynı oranlar veri setine uygulanmıştır (İlhan \& Öztürk, 2020; Yalpır vd., 2014; Ünel \& Yalpır, 2018).

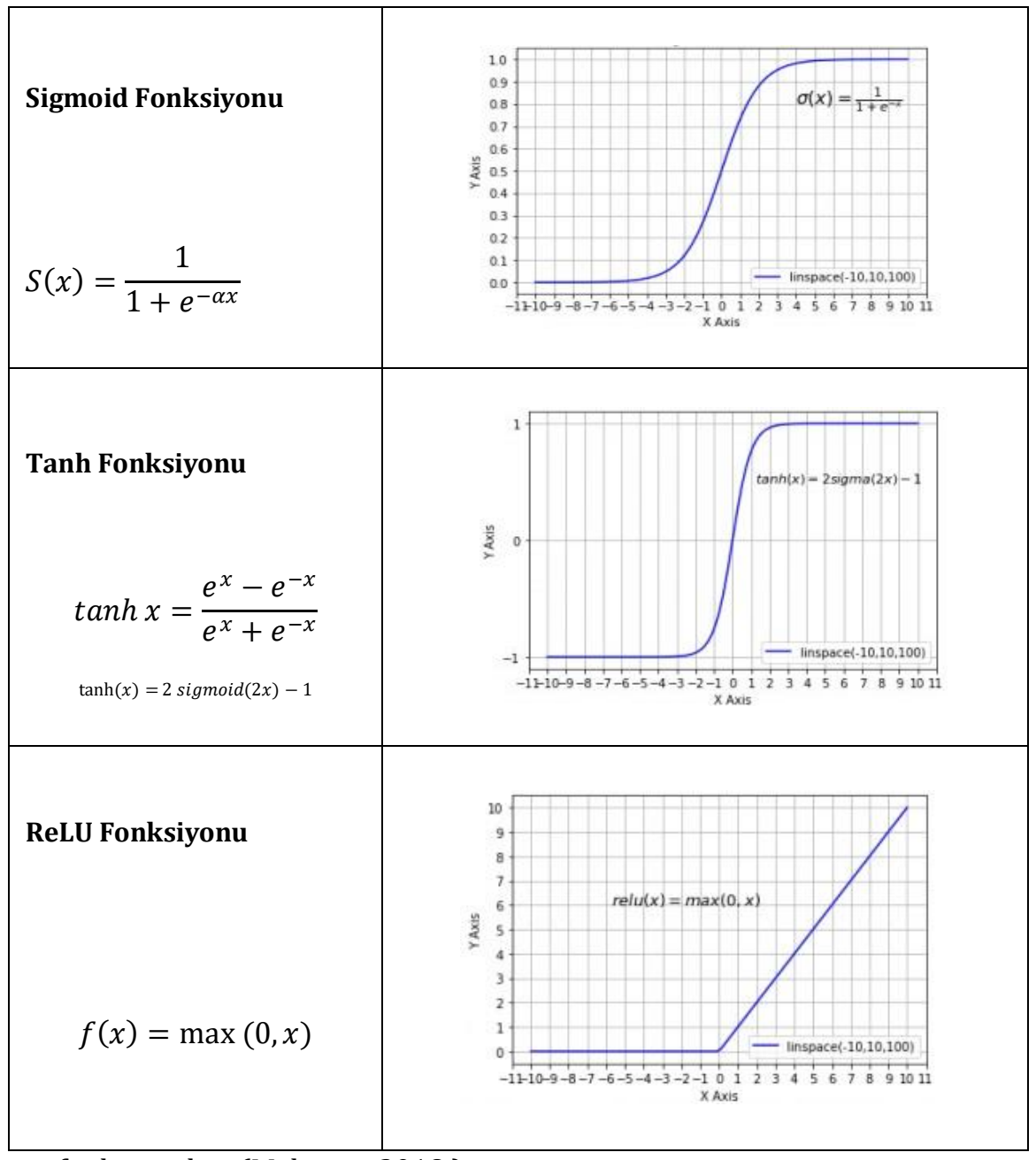

Şekil 6. Aktivasyon fonksiyonları (Makinist, 2018) 


\section{BULGULAR}

\subsection{Veri Setinin Hazırlanması}

Sarıkaya Mahallesi'nin özelliklerine uygun olarak 2/B tarım arazilerinin değerine etki eden 22 kriter belirlenmiş ve standartlaştırma kıstasları sunulmuştur (Tablo 1). Kriterler "Tapu Bilgileri, Fiziki Bilgiler,
Konum Bilgileri, Tarımsal Özellikler, Sosyal Özellikler ve Arazinin Yapısı" başlıkları altında toplanmıştır. Toplu değerleme amacıyla kriterler standartlaştırılmış ve resmi değerlerin uyușumlu olup olmadığı araștırılmıștır. Her bir örneklemin kriterlere ait verileri düzenlenerek analize hazır hale getirilmiştir.

Tablo 1. 2/B arazilerinin değer tahmini gerçekleştirilirken baz alınan kriterler ve standartları

\begin{tabular}{|c|c|c|c|c|}
\hline $\begin{array}{c}\text { Sira } \\
\text { No }\end{array}$ & $\begin{array}{l}\text { Kriter } \\
\text { No }\end{array}$ & Kriterler & Kaynaklar & Standartlar \\
\hline & $*$ & $\begin{array}{l}\text { Bağımsız } \\
\text { Değişkenler }\end{array}$ & & \\
\hline & 1. & Tapu Bilgileri & & \\
\hline & 1.1. & Ada/Parsel & & \\
\hline & 1.2. & Tașınmaz no & & \\
\hline & 2. & Fiziki Özellikler & & \\
\hline 1 & 2.1. & Geometrik Şekil & $\begin{array}{l}\text { (Başer \& Kılıç, 2016; Hurma, 2007; Koç, 2011; Demetriou, 2016; } \\
\text { Karakayacı vd., 2016; Öztürk vd., 2017) }\end{array}$ & $\begin{array}{l}\text { Kare: } 1 \text {, } \\
\text { Dikdörtgen: 2, } \\
\text { Yamuk: } 3\end{array}$ \\
\hline 2 & 2.2 . & $\begin{array}{l}\text { Nitelik } \\
\text { (Arsa, Tarla, } \\
\text { Tarım arazisi + kâgir } \\
\text { ev...) }\end{array}$ & (Hüttel vd., 2016) & $\begin{array}{l}\text { Tarla: 1, } \\
\text { Kâgir Ev+ } \\
\text { Tarla:2 }\end{array}$ \\
\hline 3 & 2.3. & Alan $\left(\mathrm{m}^{2}\right)$ & $\begin{array}{l}\text { (Hüttel vd., 2016; Koç, 2011; Demetriou, 2016; Okan \& Engindeniz, } \\
\text { 2016; Karakayacı vd., 2016; Meyer \& Früh-Müller, 2020) }\end{array}$ & $\mathrm{m}^{2}$ \\
\hline \multirow[t]{2}{*}{4} & 2.4 . & Cephe sayısı & & $\begin{array}{l}\text { Parselin kenar } \\
\text { sayısı }\end{array}$ \\
\hline & 3. & Konumsal Özellikler & & \\
\hline 5 & 3.1. & $\begin{array}{l}\text { Benzin İstasyonuna } \\
\text { Mesafe }\end{array}$ & & $\mathrm{km}$ \\
\hline 6 & 3.2. & İlçe Merkezine Mesafe & $\begin{array}{l}\text { (Başer, 2015; Plantinga \& Miller, 2001; Karakayacı vd., 2016; } \\
\text { Öztürk vd., 2017; Bozdağ \& Ertunç, 2020) }\end{array}$ & $\mathrm{km}$ \\
\hline 7 & 3.3. & En Yakın Köye Mesafe & (Bașer, 2015; Koç, 2011; Demetriou, 2018; Öztürk vd., 2017) & $\mathrm{km}$ \\
\hline 8 & 3.4. & Pazara Mesafe & (Başer, 2015; Koç, 2011; Öztürk vd., 2017) & $\mathrm{km}$ \\
\hline 9 & 3.5. & En Yakın Yola Mesafe & $\begin{array}{l}\text { (Bașer \& Dizdar, 2009; Plantinga \& Miller, 2001; Karakayacı vd., } \\
\text { 2016; Öztürk vd., 2017) }\end{array}$ & $\mathrm{km}$ \\
\hline \multirow[t]{2}{*}{10} & 3.6. & $\begin{array}{l}\text { Orman ve Mera } \\
\text { Alanlarına Mesafe }\end{array}$ & (Sylla vd., 2019; Hüttel vd., 2016) & $\mathrm{km}$ \\
\hline & 4. & Tarımsal Özellikler & & \\
\hline 11 & 4.1 & Sulama Olanakları & $\begin{array}{l}\text { (Çoşar \& Engindeniz, 2011; Koç, 2011; Demetriou, 2016; Karakayacı } \\
\text { vd., 2016; Öztürk vd., 2017) }\end{array}$ & Var: 1 Yok: 2 \\
\hline 12 & 4.2 & $\begin{array}{l}\text { Arazi Kullanım } \\
\text { Kabiliyeti }\end{array}$ & (Teknik Talimat, 2018) & 1-8 arazi sınıfı \\
\hline 13 & 4.3. & Drenaj Durumu & $\begin{array}{l}\text { (Demetriou, 2016; Dedeoğlu \& Dengiz, 2018; Meyer \& Früh-Müller, } \\
\text { 2020) }\end{array}$ & $\begin{array}{l}\text { Kötü: } 1 \text {, Orta: } 2 \text {, } \\
\text { İyi: } 3\end{array}$ \\
\hline 14 & 4.4. & Arazi Verimi & $\begin{array}{l}\text { (Başer, 2015; Hurma, 2007; Demetriou, 2018; Öztürk vd., 2017; } \\
\text { Meyer\& Früh-Müller, 2020) }\end{array}$ & $\begin{array}{l}\text { Kötü: } 1 \text {, Orta: } 2 \text {, } \\
\text { İyi: } 3\end{array}$ \\
\hline 15 & 4.5. & Taşlılık Durumu & $\begin{array}{l}\text { (Başer, 2015; Hurma, 2007; Öztürk vd., 2017; Dedeoğlu \& Dengiz, } \\
\text { 2018) }\end{array}$ & $\begin{array}{l}\text { Çok: 1, Orta: 2, } \\
\text { Az: } 3\end{array}$ \\
\hline 16 & 4.6. & Tuzluluk Durumu & (Başer, 2015; Öztürk vd., 2017) & Var: 2, Yok: 1 \\
\hline \multirow[t]{2}{*}{17} & 4.7. & Bitki Deseni & $\begin{array}{l}\text { (Hüttel vd., 2016; Gündoğmuş \& Uyar, 2016; Karakayacı vd., 2016; } \\
\text { Öztürk vd., 2017) }\end{array}$ & $\begin{array}{l}\text { Çayır: 1, Sebze: } \\
\text { 3, Ağaç: } 5\end{array}$ \\
\hline & 5. & Sosyal Özellikler & & \\
\hline 18 & 5.1. & Ulaşım Olanakları & (Karakayacı vd., 2016) & $\begin{array}{l}\text { Yok: } 1 \text {, Orta: } 2 \text {, } \\
\text { İyi: } 3\end{array}$ \\
\hline 19 & 5.2. & Arazi Piyasası & (Plantinga \& Miller, 2001; Hurma, 2007; Karakayacı vd., 2016) & $\begin{array}{l}\text { Az: 1, Orta: 2, } \\
\text { İyi:3 }\end{array}$ \\
\hline \multirow[t]{2}{*}{20} & 5.3. & $\begin{array}{l}\text { Mülkiyet Güvenliği } \\
\text { (Asayiș) }\end{array}$ & (Plantinga \& Miller, 2001) & $\begin{array}{l}\text { Az: 1, Orta: 2, } \\
\text { İyi:3 }\end{array}$ \\
\hline & 6. & Arazi Yapısı & & \\
\hline 21 & 6.1. & Erozyon Durumu & Teknik Talimat, 2018 & \\
\hline \multirow[t]{2}{*}{22} & 6.2. & Eğim & $\begin{array}{l}\text { (Asiama vd., 2018; Çoşar \& Engindeniz, 2011; Hurma, 2007; } \\
\text { Demetriou, 2016; Dedeoğlu \& Dengiz, 2018) }\end{array}$ & $\begin{array}{l}\text { Çok: } 1 \\
\text { Az:3 }\end{array}$ \\
\hline & $* *$ & Bağımlı Değişken & & \\
\hline 23 & 7. & Arazinin değeri & & \\
\hline
\end{tabular}


Arazi kullanım kabiliyeti haritası, "Toprak ve Arazi Sınıflaması Standartları Teknik Talimatı Ek 2 Arazi Kullanım Kabiliyet Sınıfları (AKK)" (Teknik Talimat, 2018) dikkate alınarak hazırlanmıștır. Arazi kullanım kabiliyeti haritasında arazi, birden sekize kadar numaralandırılmıș ve her bir numaranın karşllık geldiği nitelikler belirtilmiștir. Teknik talimattan yola çıkılarak ham veri setine AKK eklenmiștir.

Yasal özelliklerin konumsal verileri Erdemli Orman İşletme Müdürlüğü'nden, sözel verileri Erdemli Milli Emlak Müdürlüğü'nden, Fiziki ve konum bilgilerinin çoğunluğu harita üzerinden elde edilmiștir. Fiziki Özelliklerden parselin geometrik şekli, niteliği ve alanı Tapu ve Kadastro Genel Müdürlüğünün Parsel Sorgu uygulaması üzerinden; konumsal özelliklerin tamamı aynı uygulama üzerinden mesafe ölçümü özelliği kullanılarak elde edilmiştir. Tarımsal özelliklerden sulama olanakları bölgenin sulanıp sulanmaması durumuna göre puanlanmıştır. Drenaj durumu, taşlılık ve tuzluluk durumları ise AKK haritasından bölgenin puanlarının karşılık geldiği sözel anlamlardan sayısal çıkarımlar ile anlamlandırılmıștır. Bitki deseni ise arazi kullanım kabiliyetine göre bölgede yetișebilecek tarımsal ürünler dikkate alınarak eşleştirilmiştir. Sosyal özellikler olarak parselin bulunduğu konuma göre ulașım olanakları, arazi piyasası ve mülkiyet güvenliği değerlendirilip sayısal hale getirilmiștir. Arazi yapısı başlığı altındaki kriterler arazi kullanım kabiliyeti haritasındaki puanların karşılık geldiği sözel verilerden yola çıkılarak sayısal hale getirilmiştir.

Veri setinde bulunan sözel verilerin analiz edilebilmesi için sayısal formda olması gerekmektedir. Var, yok, az, çok gibi sözel veriler puanlanarak sayısal formata dönüştürülüp standartlaştırılmıștır.

Kriterler belirlendikten sonra 2/B tarım arazilerinin her biri ayrı ayrı satırlarda ve ada/parsel numaraları ile diğer özellikleri sütunda yer alacak şekilde ham veri seti matris formatında oluşturulmuştur. Bütün örneklem alınan parsellerin ham veri seti tamamlandıktan sonra normalizasyon ișlemi uygulanmıștır. Sıfır etkisiz eleman olması nedeniyle 1-2 arası normalizasyon yapılmıştır. Çünkü her bir kriterin ölçüm birimi farklıdır. Örneğin değer Türk Lirası ( vb. şeklindedir. ÇLR analizi ve YSA analizleri için hazırlanan veri setinin $\% 70$ 'i eğitim ve $\% 30$ 'u test olarak homojen șekilde ikiye bölünmüștür.

Homojen bölme işlemi şu şekilde gerçekleştirilmiştir (Tablo 2):

1.Parsellerin resmi değerleri gruplandırılmıș ve 8 sınıf elde edilmiștir.

2.Her bir gruba kaç adet 2/B parselinin girdiği tespit edilmiştir.

3.Parsel sayılarının \%70'i eğitim ve \%30'u test grubu olacak şekilde hesaplanmış ve her gruptan kaç adet parsel girmesi gerektiği belirlenmiştir.

4. Tablo 2'de gruplara göre eğitim ve test veri setleri düzenlenmiștir.

5. Parsel sayıları belirlendikten sonra çalıșma alanında homojen bir dağılım gösterecek şekilde parsel seçimleri yapılmıştır. Eğitim verileri mavi ve test verileri kırmızı renk ile harita üzerinde işaretlenmiştir (Şekil 7).
Tablo 2. Eğitim ve test grubu parsel saylları

\begin{tabular}{|c|c|c|c|c|}
\hline No & $\begin{array}{c}\text { Değer Aralıkları } \\
\text { (も) }\end{array}$ & $\begin{array}{l}\text { Parsel } \\
\text { Sayısı }\end{array}$ & $\begin{array}{l}\text { Eğitim } \\
\% 70\end{array}$ & $\begin{array}{l}\text { Test } \\
\% 30 \\
\end{array}$ \\
\hline 1 & $0-10.000$ & 54 & 38 & 16 \\
\hline 2 & $10.000-20.000$ & 137 & 96 & 41 \\
\hline 3 & $20.000-30.000$ & 116 & 81 & 35 \\
\hline 4 & $30.000-40.000$ & 54 & 38 & 16 \\
\hline 5 & $40.000-50.000$ & 22 & 15 & 7 \\
\hline 6 & $50.000-60.000$ & 14 & 10 & 4 \\
\hline 7 & $60.000-76.000$ & 11 & 8 & 3 \\
\hline 8 & $76.000-195.000$ & 6 & 4 & 2 \\
\hline & I optam & 414 & 290 & 124 \\
\hline
\end{tabular}

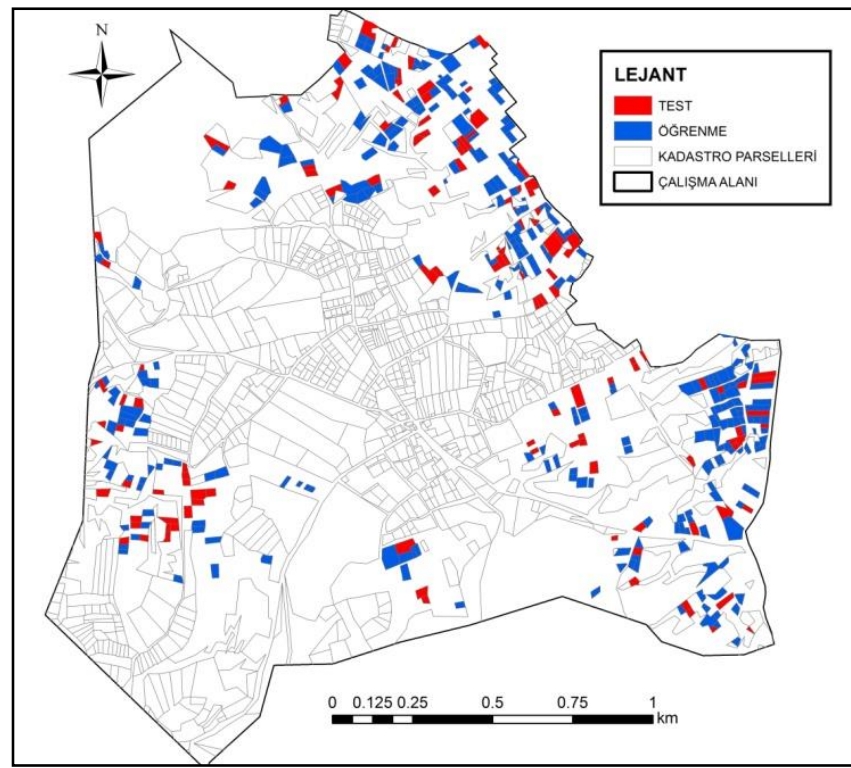

Şekil 7. Örneklem dağılımları

\section{2. Çoklu Lineer Regresyon Analizinin Modeli}

2/B tarım arazilerinin değer tahmin modelini elde etmek amacıyla birden çok bağımsız değişkenin kullanıldığı çoklu lineer regresyon (ÇLR) analizi uygulanmıştır. Bağımlı ve bağımsız değişkenlere ait veriler toplanıp matris formatında ham veri seti elde edilmiş ve normalize edilerek ÇLR analizine hazır hale getirilmiştir.

$414 * 23$ boyutundaki veri setinin \%70'lik kısmı (290 parsel) matematiksel model elde etmek, \%30'luk kısmı (124 parsel) modeli test etmek için kullanılmıștır.

290 Parsele ait normalize veriler istatistik yazılıma aktarılarak ÇLR analizi yapılmıştır. Analiz sonucunda $\mathrm{R}^{2}$ değeri 0,719 olarak hesaplanmıştır. Değer tahmininden öncelikle verilerin değer ile ilişkisi araştırılmıştır. Taşınmaz değeri bağımlı değișken, diğer kriterler ise bağımsız değişken olarak alınmış ve analiz sonrası modelin katsayıları elde edilmiștir. Modelde test verileri yerine konularak değer tahmin edilmiș ve performans analizleri gerçekleştirilmiştir.

ÇLR analizinin modeli;

Değer $=0,195+0,566^{*}$ alan $-0,0000375^{*}$ parselin geometrik ssekli $+0,007^{*}$ nitelik $-0,010^{*}$ cephe saylsı + $0,095^{*}$ benzin istasyonuna mesafe $-0,023^{*}$ orman alanina mesafe $+0,065^{*}$ ilçe merkezine mesafe $+0,020^{*}$ en yakın köye mesafe $+0,044^{*}$ pazara mesafe $+0,001^{*}$ yola mesafe $+0,017^{*}$ ulaşım olanakları $+0,042^{*}$ arazi piyasası - 
0,032*mülkiyet güvenliği - 0,013*sulama olanakları $0,063 *$ arazi kullanım kabiliyeti $+0,002 *$ drenaj durumu 0,018*bitki deseni $+0,057^{*}$ erozyon durumu -0,039*eğim

olarak hesaplanmıştır.

ÇLR modeli incelendiğinde, değere en büyük etkisi olan kriterin alan $(0,566)$ olduğu gözlenmiștir. Alanın bir birim artması ile değer 0,566 birim artacaktır. Diğer kriterlerin etkisi oldukça düşük olup alandan sonra benzin istasyonuna mesafe $(0,095)$, ilçe merkezine mesafe $(0,065)$ ve arazi kullanım kabiliyeti $(0,063)$ şeklinde sıralanmaktadır.

\subsection{Yapay Sinir Ağları Analizinin Modeli}

Normalize edilmiş veri setine "Yapay Sinir Ağları" modeli uygulanmıştır. Yazılıma girdi olarak bağımsız değişkenler, çıktı olarak da bağımlı değişken olan taşınmazların resmi değerleri atanmıştır. Şekil 8'de görüldüğü gibi ilişki kurularak öğrenmenin gerçekleşeceği sinir ağında girdi 22, çıkt 1 alınmış olup nöron sayısı 8 olarak belirlenmiştir.

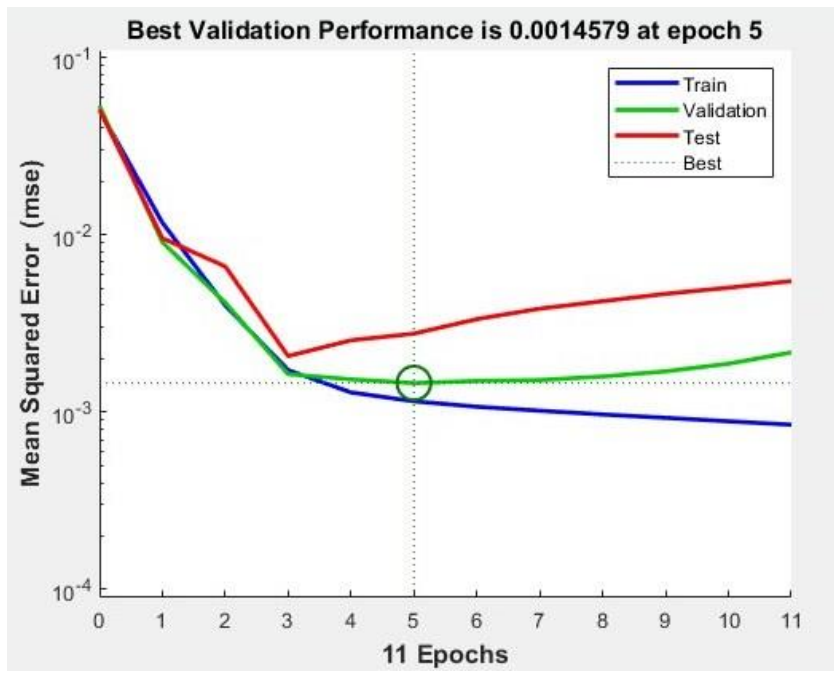

a. YSA doğrulama performansı

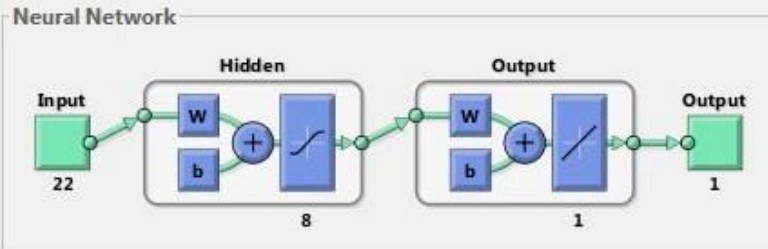

Şekil 8. Yapay sinir ağı modeli

Sinir ağında toplamda 414 parsel bulunan veri seti yine ÇLR analizine benzer şekilde \%70 (290 parsel) eğitim, \%30 (124 parsel) test amaçlı ayrılmıştır. 11 Epok iterasyon yapılarak YSA analizi gerçekleştirilmiştir (Şekil 9).

Yapay sinir ağı eğitilmiş ve elde edilen eğitim ve test verileri incelenmiştir. $\mathrm{R}^{2}$ değerinin bir ve bire yakın olması gerekmekle birlikte test değerlerinin tutarlılığı önemlidir. Çünkü sinir ağının öğrenmesi çok iyi olsa bile test aşamasında istenen doğruluk sağlanamayabilir ya da öğrenme doğruluğu çok iyi olmamasına rağmen test değeri istenen düzeyde ise bu da istenen bir durum olmayabilir. $\mathrm{Bu}$ durum sinir ağının ezber yaptığının göstergesi olarak görülebilmektedir.

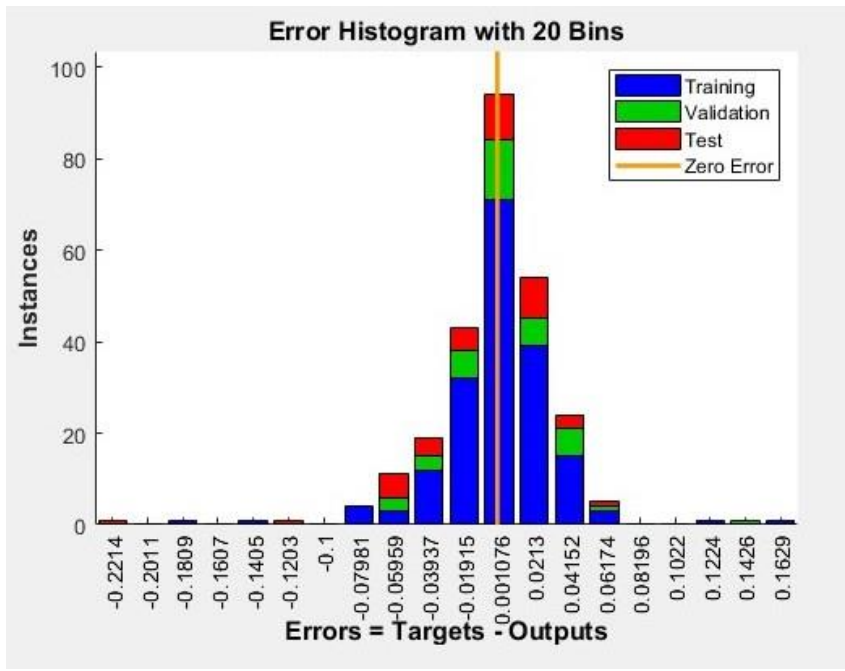

b. YSA hata histogramı

Şekil 9. Yapay sinir ağı modelinin doğrulama performansı
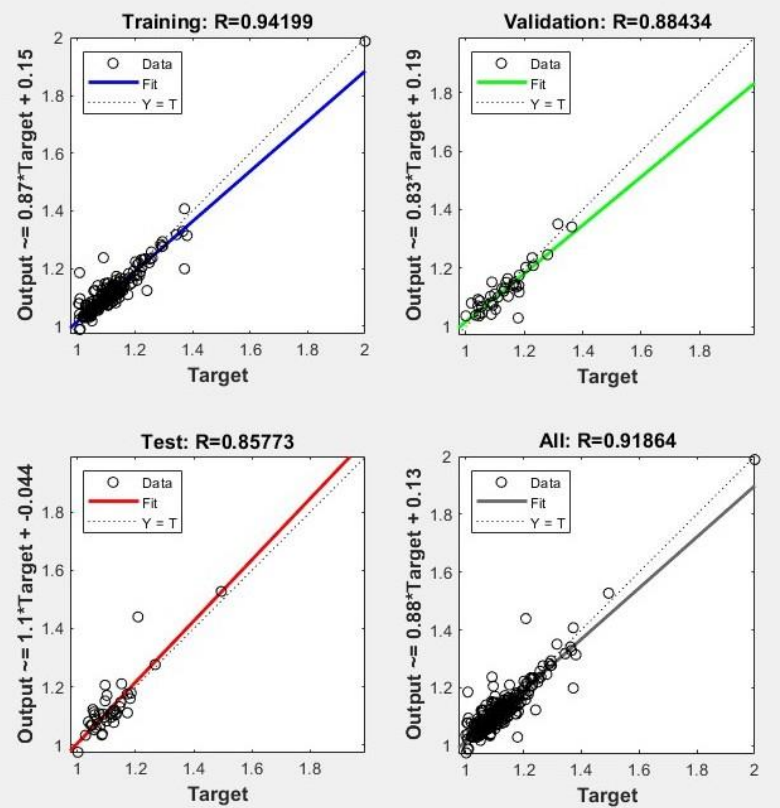

Şekil 10. YSA modelinin çıktı dağılımları ve R değeri (a) ve hata histogramı (b)

YSA doğrulama performans grafiğine göre hata miktarı azalarak 5. Epoktan sonra sabit seyretmektedir. Hata miktarının yaklaşık 0,001 olması YSA modelinde tahmin edilen değerlerin resmi değere yakın olduğu sonucu çlkmaktadır (Şekil 9).

YSA eğitim verilerinin öğretimi sonucunda model oluşmuş ve resmi değerler ile tahmin değerlerinin dağılımları elde edilmiştir. $\mathrm{R}$ değerleri incelendiğinde resmi değerlerden fazla sapma olmadı̆̆ anlaşılmaktadır (Şekil 10).

\subsection{Performans Analizi Sonuçları}

İstatiksel (ÇLR) ve modern (YSA) değerleme modelleri 2/B tarım arazilerinin verileri üzerinde uygulandıktan sonra, elde edilen tahmin değerleri ile resmi değer karşılaştırılmıştır. Bunun için modellerin performansları araștırılmıș ve resmi değeri en az hata ile tahmin edebilen model başarılı ve gerçeğe yakın sayılmıştır. 
Performans analizi için toplam dört parametre ele alınmıştır. Tahmin hatalarının mutlak değer ortalamaları alınarak "Ortalama Mutlak Hata (OMH)" (1) (Aydın, 2018), tahmin hatalarının mutlak değerlerinin resmi değere oranının ortalaması alınarak "Ortalama Mutlak Yüzde Hata (OMYH)" (2) (Veribilimcisi, 2017) ve tahmin hatalarının kareleri alınıp ortalamaların karekökten çıkarılarak "Karesel Ortalama Hata (KOH)" (3) (Demirer, 2019) hesaplanmiştir.

Ayrıca $\mathrm{R}^{2}$ (4) değerleri incelenerek tahmin edilen değerlerin resmi değeri ne kadar yansıttığ irdelenmiştir.

$$
\begin{aligned}
& O M H=\frac{1}{n} \sum_{i=1}^{n}\left|y i-y i^{\prime}\right| \\
& O M Y H=\frac{1}{n} \sum_{i=1}^{n} \frac{\left|y i-y i^{\prime}\right|}{y i} \\
& K O H=\sqrt{\frac{1}{n} \sum_{i=1}^{n}\left(y i-y i^{\prime}\right)^{2}} \\
& R^{2}=1-\frac{\sum_{i=1}^{n}\left(y_{i}-\hat{y}_{i}\right)^{2}}{\sum_{i=1}^{n}\left(\hat{y}_{i}-\bar{y}\right)^{2}}
\end{aligned}
$$

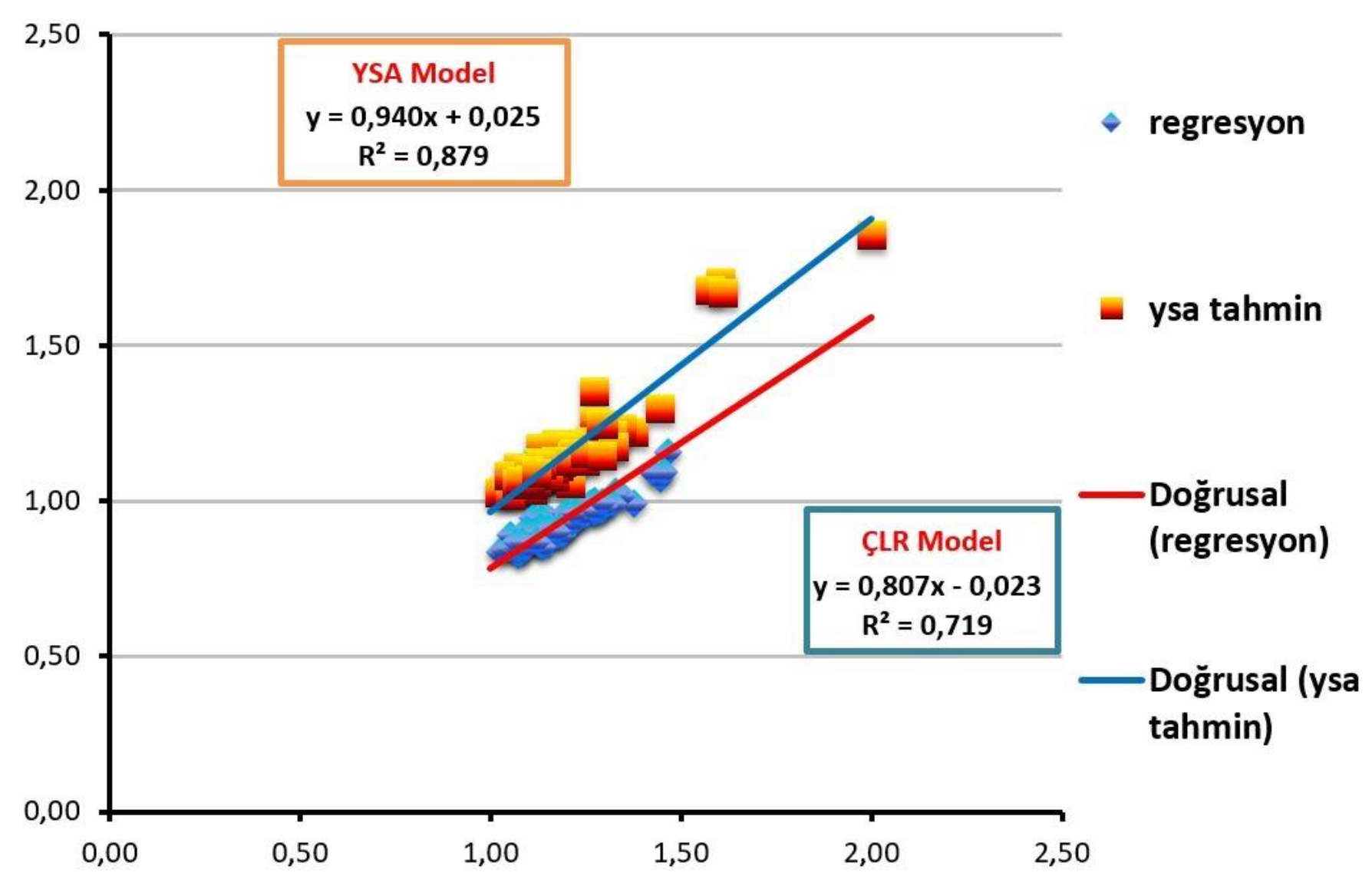

Resmi değer ve model tahmin değerlerinin farkları hesaplanarak Tablo 3'teki veriler elde edilmiştir.

Tablo 3. Performans analizi

\begin{tabular}{llll}
\hline & Değerler & ÇLR & YSA \\
\hline \multirow{4}{*}{ TEST } & $\mathrm{R}^{2}$ & 0,72 & 0,88 \\
& OMH & 0,25 & 0,09 \\
& OMYH & 0,20 & 0,07 \\
& KOH & 0,07 & 0,02 \\
\hline
\end{tabular}

ÇLR ve YSA değerleme modelleri performans analizi sonuçlarına bakıldığında YSA modelinin daha iyi sonuçlar verdiği görülmüştür. OMH, OMYH ve $\mathrm{KOH}$ değerleri, ÇLR modeline göre YSA modelindeki hata miktarlarının daha az olduğu tespit edilmiştir. Ayrıca $\mathrm{R}^{2}$ değerinin bire en yakın olan YSA modelinin daha iyi performans sergilediği görülmüştür. Bütün bu parametreler göz önüne alındığında YSA, ÇLR'ye göre tarım arazilerine ait resmi değerleri tahmin etme konusunda daha başarılı olduğu sonucuna erișilmiștir (Tablo 3).

Veri setinin \%30'luk test kısmı ile ÇLR ve YSA modellerinden elde edilen tahmin değerlerinin dağılımları incelenmiş ve eğri denklemi oluşturulmuştur. $\mathrm{R}^{2}$ değerleri incelendiğinde yine YSA sonucunun ÇLR analizine göre daha başarılı olduğu görülmüştür (Şekil 11).

Şekil 11. Modellerin performans analizi

\section{TARTIŞMA}

YSA ve ÇLR analizlerinde eğitim ve test verileri aynı taşınmazlara ait veriler ayrılarak kullanılmış ve matematiksel modellerinin değişik olmasından dolayı farklı sonuçlar elde edilmiştir. Literatürde tarım arazilerinin ele alındığı değerleme çalışmaları bulunmakta olup YSA yönteminin kullanılmasına pek rastlanmamıştır. Geçmiş dönemlerde yapılan çalışmalarda tarım arazisinin değerlemesi konusu işlenmiş (Koç, 2011; Plantinga \& Miller, 2001; Gündoğmuş \& Uyar, 2016) fakat orman vasfını 
kaybederek tarım arazisi olmuş yani 2/B arazilerinin değerlenmesi konusunda çalışmalarla fazla karşılașılmamıștır.

Literatürde tarım arazilerinin değer verilerini elde etmede anket yöntemi kullanılmıştır (Keskin, 2003; Uematsu vd., 2013; Öztürk vd., 2017). Hazırlanan bu çalışmada ise doğrudan Milli Emlak Müdürlüğü'nde resmi değerler elde edilmiştir. Değerlerin güvenilirliği bu şekilde sağlanmıştır.

Geçmiş çalışmalardaki arazi değerlemesi konusunda özellikle gelir yönteminin kapitalizasyon oranı kullanıldığı çoğunlukta olmakla birlikte arsa, konut ya da tarım arazisi değerleme işlemlerinde pek çok değerleme yöntemi görülmüştür. Bu çalışmada ÇLR ile değer tahmini gerçekleştirilmiş ve $R^{2}$ değeri 0,72 elde edilmiștir. Literatür incelendiğinde en yakın çalıșma Demetriou (2016) olup çalıșmasında tarım arazilerini ele alarak CCLR analizi uygulamıș ve $\mathrm{R}^{2}$ değerini 0,789 olarak bulmuştur. $\mathrm{R}^{2}$ değerleri arasında farklılık görülmesi çalışma alanından seçilen örneklem sayısı ve taşınmaz değerine etki ettiği düşünülen kriter sayısı ile bağlantısı olup kriter ve örneklem sayısının artması $\mathrm{R}^{2}$ değerini etkilemektedir.

Kullanılan taşınmaz cinsi konut olup değerleme modelinin ÇLR olduğu bir diğer çalışma da Tuna vd., (2015) tarafından gerçekleștirilmiștir. ÇLR analizi sonucunda $R^{2}$ değeri 0,95 elde edilmiştir. Taşınmaz cinsinin değişmesi, değere etki ettiği düşünülen kriterlerin ve kriter standartlarının değişmesi anlamına gelmektedir. Bu da kriterler arasinda meydana gelen ilişkiyi etkilemektedir.

Kullanılan iki değerleme modelinin de ortak olduğu bir çalışma olan İlhan \& Öztürk, (2020) çalışmalarında arsa fiyat tahmini gerçekleştirmek için 9 kriter ile ÇLR ve YSA değerleme modellerini kullanmışlardır. ÇLR modelinde $R^{2}$ değeri 0,89 ve YSA da ise 0,94 elde edilmiştir. $\mathrm{R}^{2}$ değerlerinin söz konusu çalışmadan yüksek olması analize alınan kriter sayısının az olması sonucunda oluşmuștur. Çünkü kriter sayısı azaldığında örneklemler arasında bağlantı kurulması ve YSA tarafından daha iyi öğrenildiği tespit edilmiştir. Söz konusu çalışmada 22 kriterin kullanılması, modellerin tahmini ile değer ve kriterler arasında ilişki kurulmasını zorlaştırmıştır.

Tablo 4'te rastgele seçilmiş olan parsellerin resmi değerleri ve YSA, ÇLR ile elde edilmiş tahmini değerler kıyaslanmıştır. Tablo 4 incelendiğinde resmi değere en yakın tahmin modeli YSA olarak görülmektedir.

Tablo 4. Değer karșılaștırması

\begin{tabular}{lccc}
$\begin{array}{l}\text { Sira } \\
\text { No }\end{array}$ & $\begin{array}{c}\text { Resmi } \\
\text { Değer(も) }\end{array}$ & $\begin{array}{c}\text { YSA Tahmin } \\
\text { Edilen Değer(も) }\end{array}$ & $\begin{array}{c}\text { CLRR Tahmin Edilen } \\
\text { Değer(も) }\end{array}$ \\
\hline 1 & $23.656,00$ & $17.341,00$ & $14.401,00$ \\
2 & $17.115,00$ & $17.094,00$ & $9.668,00$ \\
3 & $24.353,00$ & $21.535,00$ & $10.724,00$ \\
\hline
\end{tabular}

\section{DEĞER HARITTALARININ OLUŞTURULMASI}

Gerçekleștirilen regresyon analizi sonucunda Coğrafi Bilgi Sistemleri kullanılarak bölgenin değer haritası oluşturulmuştur. Bunun için ArcGIS 10.3 yazıllımı kullanılmıştır.

Öncelikle Sarkaya mahallesinin kadastro durumu, bölgedeki bütün 2/B araziler ve örneklem 2/B arazilerin grafik verileri vektörel formatta yazılıma aktarılmıştır. Örneklemlerin öznitelik tablosunda bulunan veriler ve öncesinde hesaplanmış olan tahmin değerleri, grafik veriler ile birleştirilmiştir. Böylelikle grafik veri ile analizi sonuçları eşleştirilmiştir. Değer haritası oluşturmak için jeoistatistik analizinin Kriging/CoKriging yöntemi kullanılmıştır. ÇLR ve YSA modeli sonucu elde edilen değer tahmin haritaları üretilmiştir (Şekil 12). Değer haritaları görsel olarak incelendiğinde resmi değer haritasına YSA modelinden elde edilen değer tahminleriyle oluşturulan haritanın daha yakın bir sonuç elde edildiği görülmektedir. Özellikle resmi değer ve YSA tahmin değer haritasında yeşil, turuncu, lacivert ve mavi bölgelerin dağılımları yaklaşık birbirine benzerlik gösterirken ÇLR tahmin değer haritasının farklılaştığı gözlenmiştir. Bu da YSA yönteminin tercih edilebilir modern değerleme yöntemleri arasında kılmaktadır.

\section{SONUÇLAR}

Taşınmaz değerleme, üzerinde daha fazla araştırma ve çalışma yapılması gereken bir konudur. Gayrimenkul değerleme uzmanları, harita mühendisleri, inşaat mühendisleri ve diğer disiplinler birçok çalışma gerçekleştirmesine karşın gelişen teknolojiye paralel yeterli olmamaktadır. Taşınmazın değerinin bilinmesi; vergilendirme, kamulaştırma, devletleștirme, özelleştirme vb. uygulamalarda kullanımı mümkün kıldığından en doğru tahmin modelinin üretilmesi önem arz etmektedir.

Taşınmaz değerlemeye ilgi arttıkça kullanılan geleneksel yöntemlere alternatif uygulamalar da kullanılmaya başlanmıștır. Bu alternatif uygulamalarda manuel değer hesaplamanın dışında işin içine bilgisayar zekâsı, hızı ve hassasiyeti de dâhil edilmiștir. Çünkü teknolojinin gelişmesi taşınmaz değerlemenin insana bağımlı bir iş olması olayını azaltmaktadır. Değeri; daha objektif, gerçeğe yakın ve kontrol edilebilirliği yüksek hale getirmektedir. Modern değerlemenin bir diğer iyi yanı veri seti kalabalık olan değerleme işlemlerinde değerin daha kolay ve hızlı hesaplanmasını kolaylaştırmasıdır. $\mathrm{Bu}$ yüzden taşınmaz değerleme işlemlerinde modern taşınmaz değerleme yöntemleri kullanımı artmıștır.

Gerçekleştirilen bu çalışmada Mersin ili Erdemli ilçesi Sarıkaya mahallesinin 2/B arazilerinin değer tahmini gerçekleştirilmiştir. Taşınmazların, çok kriterli regresyon analizi ve yapay sinir ağları yöntemiyle değer tahminleri gerçekleştirilmiştir. ÇLR analizi sonucunda, her bir kriterin değere etki ettiği oranda bir kat sayı hesaplanmaktadır ve elde edilen katsayılarla bir regresyon modeli oluşturulmaktadır. YSA ise karakutu adı verilen gizli katmanlar içerisinde işlemleri gerçekleștirmekte olup kriterlerin ağırlıkları görülememektedir. 

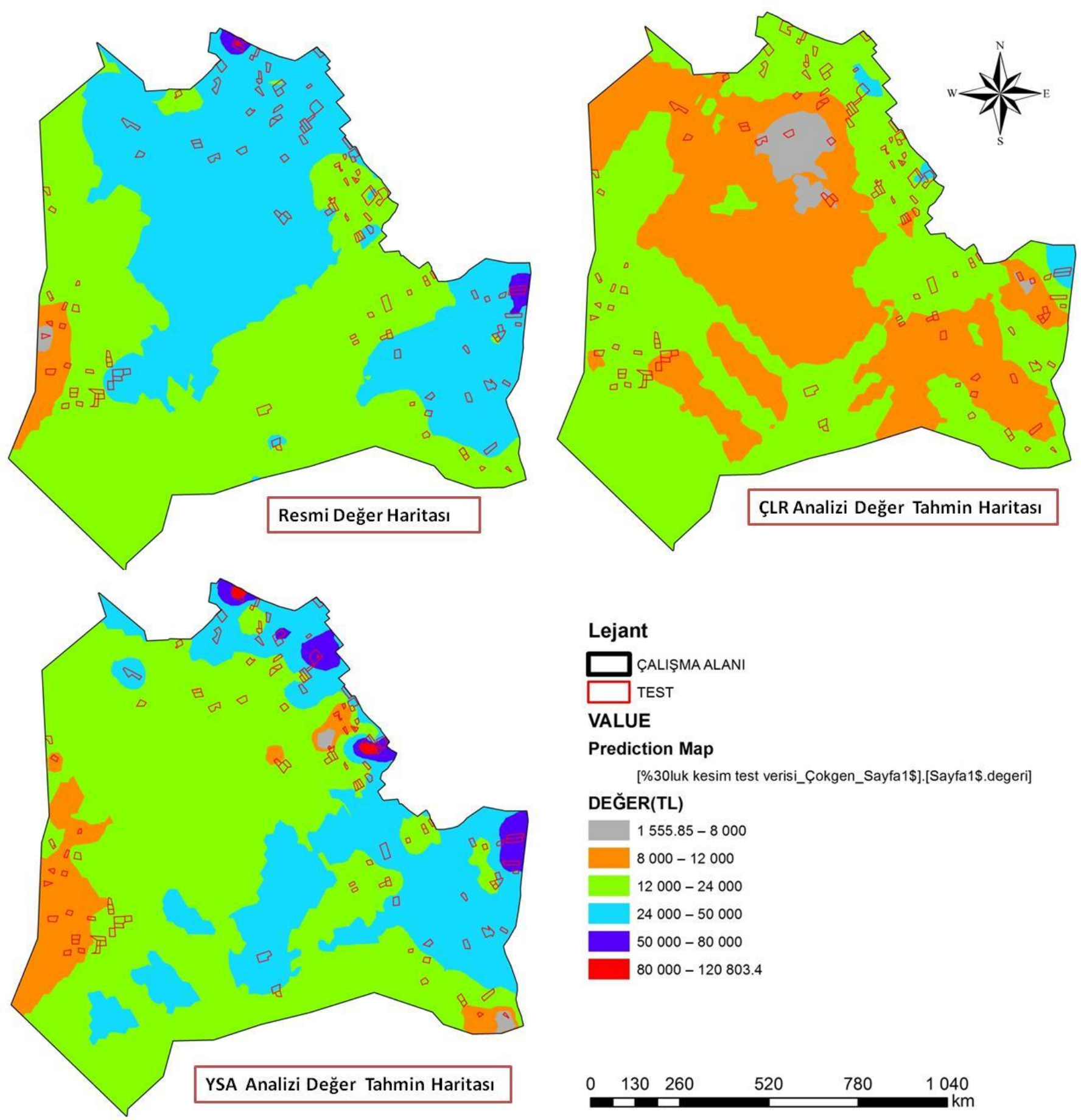

\section{Prediction Map}

[\%30luk kesim test verisi_Çokgen_Sayfa1\$].[Sayfa1\$.degeri] DEĞER(TL)

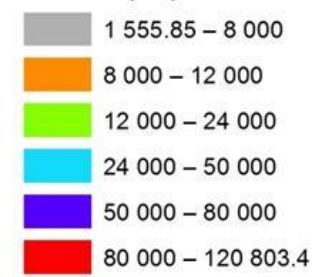

Şekil 12. ÇLR ve YSA modellerinin değer tahmin haritaları

ÇLR ve YSA tahminlerinin hataları kıyaslandığında YSA modelinden elde edilen tahmin değerlerinin daha iyi sonuçlar verdiği gözlenmiștir. YSA modelinin bir handikabı olarak değere etki eden bağımsız kriterlerin sayısı arttıkça doğru tahmin edebilme yeteneğinin azalması gösterilebilir. Fakat sinir ağının ilişki kuracağı kriter sayısı azaltılıp sinir ağında bulunan nöron sayısı arttırılırsa tahmin değerinin gerçek değere daha fazla yaklaştığı gözlemlenmiştir.

$\mathrm{Bu}$ çalışmada elde edilen tarım arazileri değer haritası değerleme konusu ile ilgili bütün uygulamalara altlık olabilecektir. Özellikle 2/B tarım arazilerinin satışı söz konusu olduğunda toplu değerleme yapılabilecektir. Gelecekte arazi toplulaştırma projeleri değer esaslı yapıldığında öneminin daha da artacağı düşünülmektedir.

\section{BİLGILENDIRME/TEŞEKKÜR}

Çalışmada kullanılan veriler konusunda yardım ve desteklerini esirgemeyen Erdemli Milli Emlak Müdürlüğü, Erdemli Orman İşletme Müdürlüğüne ve diğer ilgili bütün kurum ve kuruluşlara teșekkür ederiz.

\section{ARAŞTIRMACILARIN KATKI ORANI}

Sultan Çinar: Araştırma, veri toplama, ÇLR ve YSA analizlerini yapma, haritaları hazırlama ve makale 
yazma; Fatma Bünyan Ünel: Analiz sonuçlarını yorumlama ve düzenleme.

\section{ÇATIŞMA BEYANI}

Herhangi bir çıkar çatışması bulunmamaktadır.

\section{KAYNAKÇA}

Açlar A \& Çağdaş V (2008). Taşınmaz (Gayrimenkul) Değerlemesi. Ankara: TMMOB Harita ve Kadastro Mühendisleri Odası.

Akış B (2013). İstatistiki Yöntemlerle Değer Belirleme ve Değer Haritası Üretimi - Selçuklu Örneği. Yüksek Lisans Tezi, Selçuk Üniveristesi, Fen Bilimleri Enstitüsü, Harita Mühendisliği ABD, Konya.

Alpaslan H İ (2015). TMS/TFRS Kapsamında Gayrimenkul Değerleme ve Gerçeğe Uygun Değerin Tespitinde Emsal Karşılaştırma ve Gelir İndirgeme Yöntemleri Üzerine Bir Uygulama. Nevșehir $\mathrm{Hacl}$ Bektaşi Veli Üniversitesi, Sosyal Bilimler Enstitüsü Dergisi, 4, 17-35.

Anayasa (1982). 2709 Sayll Türkiye Cumhuriyeti Anayasası, Kabul tarihi: 18/10/1982, Yayımlandığı Resmi Gazete: Tarih: 9/11/1982, Sayl: 17863 (Mükerrer), Yayımlandığı düstur: Tertip: 5 Cilt: 22.

Asiama K O, Bennett R, Zevenbergen J \& Asiama S O (2018). Land valuation in support of responsible land consolidation on Ghana's rural customary lands. Survey Review, 50(361), 288-300. https://doi.org/10.1080/00396265.2018.1467672

Aydın C (2018). Makine Öğrenmesi Algoritmaları Kullanılarak İtfaiye İstasyonu İhtiyacının Sinıflandirilması. European Journal of Science and Technology, 14, 169-175. https://doi.org/10.31590/ejosat.458613

Bahar M E (2007). Taşınmaz Değerlemesinde CBS'nin Kullanım Olanakları. Yüksek Lisans Tezi, İstanbul Teknik Üniversitesi, Fen Bilimleri Enstitüsü, Geomatik Mühendisliği ABD, İstanbul.

Başer U (2015). Samsun İli Ladik İlçesinde Arazi Fiyatlarını Etkileyen Faktörlerin Belirlenmesi. Yüksek Lisans Tezi, Ondokuz Mayıs Üniversitesi, Fen Bilimleri Enstitüsü, Tarım Ekonomisi ABD, Samsun.

Başer U \& Kılıç O (2016). Arazi Fiyatlarını Etkileyen Faktörlerin Belirlenmesi: (Samsun İli Ladikli İlçesi). 12. Ulusal Tarım Ekonomisi kongresi, 273-280.

Başer V \& Dizdar Y S (2009). Tarim Arazisinden İmar Parseline Geçiște Değerleme İșlemlerinin Coğrafi Bilgi Sistemi (CBS) Tabanli Nominal Değerleme Yöntemi Kullanılarak İrdelenmesi. TMMOB Harita ve Kadastro Mühendisleri Odası 12. Türkiye Harita Bilimsel ve Teknik Kurultayl.

Bayar R (2018). Arazi kullanımı açısından Türkiye'de tarım alanlarının değişimi. Coğrafi Bilimler Dergisi, 16(2), 187-200.

https://doi.org/10.1501/cogbil_0000000197

Beșer G (2015). Yapay Sinir Ağları Yöntemi ile Gayrimenkul Değerleme. Erişim tarihi 12.03.2020 https://goktugbeser.com/yapay-sinir-aglariyontemi-ile-gayrimenkul-degerleme/

Bozdağ A \& Ertunç E (2020). CBS ve AHP Yöntemi Yardımıyla Niğde Kenti Örneğinde Tașınmaz
Değerleme. Geomatik, 5(3), 228-240. https://doi.org/10.29128/geomatik.648900

Bulut B N (2011). YSA ve DVM Yöntemleri ile Tașınmaz Değerlemesi için Bir Yaklaşım Geliştirme. Yüksek Lisans Tezi, Selçuk Üniversitesi, Fen Bilimleri Enstitüsü, Elektronik ve Bilglisayar Sistemleri Eğitimi ABD, Konya.

Çoşar G Ö \& Engindeniz S (2011). Tarım Arazilerinin Değerlemesinde Coğrafi Bilgi Sisteminden Yararlanma Olanakları. Ege Üniversitesi Ziraat Fakültesi Dergisi, 48(3), 283-290. https://doi.org/10.20289/eüzfd.37475

Dedeoğlu M \& Dengiz O (2018). Coğrafi Bilgi Sistemleri ile Entegre Edilen Çok Kriterli Karar Destek Analiz Yaklaşımı Kullanılarak Arazi Uygunluk Sınıflarının Belirlenmesi. Süleyman Demirel Üniversitesi Ziraat Fakültesi Dergisi, 13(2), 60-72.

Demetriou D (2016). The assessment of land valuation in land consolidation schemes: The need for a new land valuation framework. Land Use Policy, 54, 487498.

https://doi.org/10.1016/j.landusepol.2016.03.008

Demetriou D (2018). Automating The Land Valuation Process Carried Out In Land Consolidation Schemes. Land Use Policy, 75, 21-32.

https://doi.org/10.1016/j.landusepol.2018.02.049

Demirer A 0 (2019). Gözlemlerde Hatalar Teorisi. Ölçme Bilgisi.

Derinpınar M A \& Aydınoğlu A Ç (2015). Bulanık Mantık ile Coğrafi Bilgi Teknolojilerini Kullanarak Taşınmaz Değerlemesi. TMMOB Harita ve Kadastro Mühendisleri Odası 15. Türkiye Harita Bilimsel ve Teknik Kurultayl.

Emlak Vergisi (1970). 1319 Sayılı Emlak Vergisi Kanunu, Kabul tarihi: 29/07/1970, Yayımlandığı Resmi Gazete: Tarih: 11/08/1970 Sayl: 13576, Yayımlandığı düstur: Tertip: 5 Cilt: 9 Sayfa: 2662.

Engindeniz S (2010). Tarım Arazilerinin Kamulaştırılmasında Gelir Yöntemin Uygulama Esasları. TKB Türktarım Dergisi, 192, 53-57.

Engindeniz S, Cansu B \& Betül S (2015). Tarım Arazilerinin Kamulaştırma Bedellerinin Saptanmasında Gelir Yönteminin Uygulanmasıyla İlgili Anlaşmazlıklar. TMMOB Harita ve Kadastro Mühendisleri Odası 15. Türkiye Harita Bilimsel ve Teknik Kurultayı, 15, 25-28.

Erdem N (2017). Türkiye için Bir Taşınmaz Değerleme Sistemi Yaklaşımı. Geomatik Dergisi, 2(1), 18-36.

Erdem N (2018a). Türkiye Taşınmaz Değerleme Sisteminin Yeniden Yapılandırılmasına Yönelik Bilimsel Çalışma ve Öneriler Üzerine Bir Değerlendirme. Ömer Halisdemir Üniversitesi Mühendislik Bilimleri Dergisi, 7(1), 159-170. https://doi.org/10.28948/ngumuh.386408

Erdem N (2018b). Türkiye'de Taşınmaz Değerleme Alanında Yapılan Lisansüstü Tezlerinin İçerik Analizi. Academic Platform-Journal of Engineering and Science, 1, 112-126. https://doi.org/10.21541/apjes.332681

Erdem N (2019). Türkiye Taşınmaz Değerleme Sisteminin Etkinliğinin Araştırılması. Geomatik Dergisi, 4(1), 1-13.

https://doi.org/10.29128/geomatik.418870 
Ergin M (2013). Gayrimenkul Türlerine Göre Değerleme Raporlarının Analizi. Yüksek Lisnans Tezi, Marmara Üniversitesi, Sosyal Bilimler Enstitüsü, İșletme ABD, İstanbul.

Gökgöz F (2020). Çoklu Regresyon Analizi. https://acikders.ankara.edu.tr/pluginfile.php/11732 6/mod_resource/content/1/11-Coklu Regresyon 1.pdf

Gökkuș A (2018). Meralarımız ile ilgili bir değerlendirme. TÜRKTOB Dergisi, 25, 6-8.

Göksel Ç \& Balçık F B (2019). Land Use And Land Cover Changes Using Spot 5 Pansharpen Images; A Case Study in Akdeniz District, Mersin-Turkey. Turkish Journal of Engineering, 3(1), 32-38. https://doi.org/10.31127/tuje.444685

Gültepe Y (2019). Makine Öğrenmesi Algoritmaları ile Hava Kirliliği Tahmini Üzerine Karşılaștırmalı Bir Değerlendirme. European Journal of Science and Technology, 16, 8-15. https://doi.org/10.31590/ejosat.530347

Gündoğmuş M E \& Uyar T (2016). Kestane Bahçelerinde Gelir Yöntemine Göre Değerleme: Aydın İli Nazilli İlçesi Örneği. Namık Kemal Üniversitesi Tekirdağ Ziraat Fakültesi Dergisi, 13(1), 107-117.

Hazine Taşınmazlarının İdaresi Hakkında Yönetmelik, (2007). Resmî Gazete Tarihi: 19.06.2007, Sayısı: 26557.

Hışır M (2009). Türkiye'de Taşınmaz Değerleme ve Harita Mühendisliği. TMMOB Harita ve Kadastro Mühendisleri Odası, 12. Türkiye Harita Bilimsel ve Teknik Kurultayı.

Hurma H (2007). Çevre Kalitesinin Tarımsal Arazi Değeri Üzerine Etkilerinin Analizi: Trakya Örneği. Doktora Tezi, Namık Kemal Üniversitesi, Fen Bilimleri Enstitüsü, Tarım Ekonomisi ABD, Tekirdağ.

Hüttel S, Wildermann L \& Croonenbroeck C (2016). How do institutional market players matter in farmland pricing? Land Use Policy, 59, 154-167. https://doi.org/10.1016/j.landusepol.2016.08.021

İlhan A T \& Öztürk S (2020). Yapay Sinir Ağlarının Gayrimenkullerin Toplu Değerlemesinde Uygulanabilirliği: Gölbaşı İlçesi Örneği. Hacettepe Üniversitesi, Sosyal Bilimler Dergisi, 2(2), 160-188.

İmar (1983). 3194 Sayılı İmar Kanunu, Kabul tarihi: 3/5/1985, Yayımlandığı Resmi Gazete; Tarih: 9/5/1985, Sayı: 18749, Yayımlandığı düstur: Tertip: 5, Cilt: 25, Sayfa: 378.

Kadastro (1987). 3402 Sayılı Kadastro Kanunu, Kabul tarihi: 21/6/1987, Yayımlandığı Resmi Gazete: Tarih: 9/7/1987, Sayı:19512, Yayımlandığı Düstur: Tertip: 5 Cilt: 26, Sayfa: 229.

Kamulaştırma (1983).2942 Sayılı Kamulaştırma Kanunu, Kabul tarihi: 4/11/1983, Yayımlandığı Resmi Gazete; Tarih: 8/11/1983, Sayl: 18215, Yayımlandığı düstur: Tertip: 5, Cilt: 22 Sayfa sayısı: 843.

Karaca S S \& Yayar R (2014). Konut Fiyatlarına Etki Eden Faktörlerin Hedonik Modelle Belirlenmesi: TR83 Bölgesi Örneği. Ege Akademik Bakis (Ege Academic Review), 14(4), 509-509. https://doi.org/10.21121/eab.2014418008

Karakayacı Z, Oğuz C \& Reis S (2016). Konya İli Çumra İlçesindeki Tarım Arazilerinin Değerlerini Etkileyen
Faktörlerin Farklı Yaklaşımlarla Analizi. Tarım Ekonomisi Dergisi, 22(2), 17-27.

Karakayacı Ö \& Karakayacı Z (2012). Kentsel Saçaklanma Alanlarında Arsa/Arazi Değerini Belirlemeye Yönelik Yöntem Önerisi. The Journal of Academic Social Science Studies, 5(4), 107-120. https://doi.org/10.9761/jasss_98

Keskin G (2003). Tarım Arazilerinin Kamulaştırmasında Değer Biçme: Akyar Barajı Örneği. Akdeniz İ̈BF Dergisi, 5, 91-107.

Koç M (2011). Tarım Arazisi Fiyatları Üzerine Etkili Olan Faktörlerin Ekonometrik Analizi: Kırıkkale İli Keskin İlçesi Örneği. Doktora Tezi, Ankara Üniversitesi Fen Bilimleri Enstitüsü. Tarım Ekonomisi ABD, Ankara.

Köktürk E (2009). Taşınmaz Değerleme: Durum Saptamasi ve Yönelimler. TMMOB Harita ve Kadastro Mühendisleri Odası 12. Türkiye Harita Bilimsel ve Teknik Kurultayı.

Makinist S (2018). Derin Öğrenme (Yapay Sinir Ağları3) http://buyukveri.firat.edu.tr/2018/04/16/derinogrenme-yapay-sinir-aglari-3/) Erişim Tarihi: 12.03.2021

Mete M O \& Yomralığlu T (2019). CBS ile Nominal Taşınmaz Değer Haritası Üretiminde Çözünürlük Araştırması. Türkiye Arazi Yönetimi Dergisi, 1(1), 1623.

https://dergipark.org.tr/en/pub/tayod/issue/5059 $0 / 651684$

Meyer M A \& Früh-Müller A (2020). Patterns and drivers of recent agricultural land-use change in Southern Germany. Land Use Policy, 99 (November 2019), 104959. https://doi.org/10.1016/j.landusepol.2020.104959

Milli Emlak Genel Tebliği $21 \quad 1$ (2020). http://mpoc.org.my/malaysian-palm-oil-industry/

Veribilimcisi (2017). MSE, RMSE, MAE, MAPE ve Diğer metrikler. Erişim Tarihi:11.03.2021 https://veribilimcisi.com/2017/07/14/mse-rmsemae-mape-metrikleri-nedir/

Okan N \& Engindeniz S (2016). İzmir'in Selçuk İlçesindeki Şeftali Bahçelerinin Gelir Yöntemiyle Değerlemesi Üzerine Bir Araştırma. Ege Üniveristesi Ziraat Fakültesi Dergisi, 53(2), 139-146.

Orman (1956). 6831 Sayılı Orman Kanunu, Kabul Tarihi: 31/8/1956, Yayımlandığ resmi gazete: Tarih: 8/9/1956, Sayı: 9402, Yayımlandığı düstur: Tertip: 3 Cilt: 37, Sayfa: 2457.

Özen A \& Şişman A (2019). Taşınmaz Değer Haritası Üretiminde Konumsal Analiz - Bolu Örneği. 4. International Symposium on Innovative Approaches in Engineering and Natural Sciences, 4(6), 142-147.

Özkan G \& Yalpır Ş (2005). Taşınmaza Ekonomik Bakış ve Değerlendirmesi. TMMOB Harita ve Kadastro Mühendisleri Odası 10. Türkiye Harita Bilimsel ve Teknik Kurultayl.

Öztürk G, Engindeniz S \& Bayraktar Ö V (2017). İzmir deki Sulanabilir Tarım Arazilerinin Değerini Etkileyen Faktörlerin Analizi. Selcuk Journal of Agricultural and Food Sciences, 31(3), 75-87. https://doi.org/10.15316/sjafs.2017.38

Öztürk K \& Şahin M E (2018). Yapay Sinir Ağları ve Yapay Zekaya Genel Bir Bakış. Takvimi Vekayi, 6(2), 25-36. 
http://www.sloi.org/sloi-name-of-this-article

Plantinga A J \& Miller D J (2001). Agricultural land values and the value of rights to future land development. The Economics of Land Use, 77(1), 243-254. https://doi.org/10.4324/9781315240114-17

Saraç E (2012). Yapay Sinir Ağları Metodu ile Gayrimenkul Değerleme. Yüksek Lisans Tezi, İstanbul Kültür Üniversitesi, Fen Bilimleri Enstitüsü, İnşaat Mühendisliği ABD, İstanbul.

Sarıkaya Erdemli (2020). Sarıkaya bilgilendirme, https://www.turkcebilgi.com/sar\%C4\%B1kaya,_erd emli Erișim tarihi: 23.05.2020

Savuran O İ (2008). Gayrimenkul Fiyat Endeksleri ve İstanbul Etiler Bölgesinde Konutlar için Hedonik Fiyat Endeksi Uygulaması. Yüksek Lisans Tezi, İstanbul Teknik Üniversitesi, Fen Bilimleri Enstitüsü, Gayrimenkul Geliștirme ABD, İstanbul.

Selim S \& Demirbilek A (2009). Türkiyedeki Konutların Kira Deeğrinin Analizi: Hedonik Model ve Yapay Sinir Ağları Yaklașımı. Aksaray Üniversitesi İIBF Dergisi, 1(1), 168-169.

Sever (2019). Verimli Tarım Arazisine Sahip Olmak Bir Ülkenin Dünü, Bugünü ve Geleceğidir http://www.turktarim.gov.tr/Haber/238/verimlitarim-arazisine-sahip-olmak-bir-ulkenin-dunubugunu-ve-gelecegidir- Erişim Tarihi: 23.05.2020

Sylla M, Lasota T \& Szewrański S (2019). Valuing environmental amenities in peri-urban areas: Evidence from Poland. Sustainability (Switzerland), 11(3). https://doi.org/10.3390/su11030570

Şengöz N (2017). Yapay Sinir Ağları. https://www.derinogrenme.com/2017/03/04/ yapay-sinir-aglari/ Erişim Tarihi: 12.03.2021

Tapu (1983). 2892 Sayılı Tapu Kanunu, Kabul tarihi: 22/12/1934, Yayımlandığı Resmi Gazete; Tarih: 29/12/1934, Yayımlandığı Düstur: Tertip: 3, Cilt: 16, Sayfa: 312.

Taşkıran A H (2021). Aktivasyon Fonksiyonları https://www.akademianinbahcesi.com/aktivasyon_f onksiyonlari/ Erişim tarihi: 12.03.2021

Teknik Talimat (2018). Toprak ve Arazi Sinıflaması Standartları Teknik Talimatı; Tarım Arazilerinin Korunması Kullanılması ve Planlanmasına Dair Uygulama Talimatı, 26/04/2018 tarihli 68656427020-E.1167396 sayılı Müsteşarlık Evrakı.

Tuna M F, Türk T \& Kitapçı O (2015). Lineer Regresyon ve Coğrafi Bilgi Sistemleri Yardımıyla Ev Fiyatlarının Tahmin Edilmesi : Ankara Örneği. TMMOB Harita ve Kadastro Mühendisleri Odası 15. Türkiye Harita Bilimsel ve Teknik Kurultayı, 1-5.
TÜİK (2020). 2020 Adrese Dayalı Nüfus Kayıt Sistemi,https://biruni.tuik.gov.tr/medas/?locale=trE rișim Tarihi: 02.03.2021

TMK (2001). 4721 Sayılı Türk Medeni Kanunu, Kabul tarihi: 22/11/2001, Yayımlandığı Resmi Gazete tarihi: 8/12/2001, Sayı: 24607, Yayımlandığı Düstur; Tertip: 5, Cilt: 41.

Uematsu H, Khanal A R \& Mishra A K (2013). The impact of natural amenity on farmland values: A quantile regression approach. Land Use Policy, 33, 151-160. https://doi.org/10.1016/j.landusepol.2012.12.007

Ünel F B \& Yalpır Ş (2013). Grouping and Analyzing of Real Estate Valuation. International Journal of Multidisciplinary Thought, 3(1), 171-182.

Ünel F B \& Yalpır Ş (2018). Application Artificial Neural Network in Mass Real Estate Appraisal for Centre Neighborhood of Konya. International Conference on Advanced Technologies, Computer Engineering and Science (ICATCES'18), Figure 1, 575-578.

Ünel F B \& Yalpır Ş (2019). Türkiye'de Taşınmazların Değerini Etkileyen Kriterlere Yaklaşım. Geomatik Dergisi, 4(2), 112-133. https://doi.org/10.29128/geomatik.499681

Vergi Usul (1961). 213 Sayılı Vergi Usul Kanunu, Kabul Tarihi: 4/1/1961, Yayımlandığı Resmi Gazete; Tarih: 10/1/1961 Sayı: 10703, Yayımlandı̆̆ı düstur: Tertip: 4, Cilt: 1, Sayfa: 1037.

Yalpir S, Durduran S S, Unel F B \& Yolcu M (2014). Creating a valuation map in GIS through artificial neural network methodology: A case study. Acta Montanistica Slovaca, 19(2), 79-89.

Yalpır Ş \& Ünel F B (2016). Türkiyede ve Uluslararası Çalışmalarda Arsa Değerlemede Kullanılan Kriterlerin İrdelenmesi ve Faktör Analizi ile Azaltımı. Afyon Kocatepe University Journal of Sciences and Engineering, 16(2), 303-322. https://doi.org/10.5578/fmbd.28134

Yılmaz O S, Gülgen F, Güngör R \& Kadı F (2018). Uzaktan Algılama Teknikleri ile Arazi Kullanım Değişiminin İncelenmesi: Köprübașı İlçesi Örneği. Geomatik Dergisi, 3(3), 233-341. https://doi.org/10.29128/geomatik.410987

Zhang J, Mishra A K, Hirsch S \& Li X (2020). Factors affecting farmland rental in rural China: Evidence of capitalization of grain subsidy payments. Land Use Policy, 90 (August 2019), 104275. https://doi.org/10.1016/j.landusepol.2019.104275 